\title{
The Role of the Danish Constitution in European and Transnational Governance
}

\author{
Helle Krunke and Trine Baumbach
}

\begin{abstract}
The Danish Constitution originates from 1849. Its human rights catalogue, which stems from 1953, is described in the report as old and not very comprehensive; in many cases the ECHR goes further in protection. Denmark does not have a constitutional court, and courts take a deferential approach to judicial review; up until 2015, only one Act had been annulled on the grounds of unconstitutionality. The Danish concept of democracy builds on a strong Parliament and reluctant courts, which are careful not to act in a 'political' manner. Regarding constitutional amendments, the Danish Constitution has not undergone changes in relation to EU membership. This is partly attributed to the difficult amendment procedure involving two (different) referendums and a high turnout requirement. In practice, Danish parliamentary control over Government in EU decision-making has widely come to be regarded as one of the strongest in Europe. However, with regard to domestic implementation, in 2015 Parliament expressed concern that the
\end{abstract}

Helle Krunke is Professor of Constitutional Law, Centre for European and Comparative Legal Studies (CECS), Faculty of Law, University of Copenhagen, Denmark, and First Vice-President and member of the Executive Committee for the International Association of Constitutional Law (IACL). e-mail: Helle.Krunke@jur.ku.dk.

Trine Baumbach is Professor of Criminal Law, Centre for Public Regulation and Administration (CORA), Faculty of Law, University of Copenhagen, Denmark. e-mail: Trine.Baumbach@jur. ku.dk.

Helle Krunke wrote Part 1, Part 2, Sects. 2.1, 2.2, 2.4-2.13 and Part 3. Trine Baumbach wrote Part 2 and Sect. 2.3. We would like to thank the student assistants who assisted us in gathering the relevant material for the questionnaire: Stine Frey, Marieke Mitchel, Kirstine Mose and Sofia Cerqueira Rasmussen.

All websites accessed 1 December 2015. Text submitted 22 June 2015.

H. Krunke ( $\square)$

Faculty of Law, Centre for European and Comparative Legal Studies (CECS), University of Copenhagen, Copenhagen, Denmark

e-mail: Helle.Krunke@jur.ku.dk

T. Baumbach

Faculty of Law, Centre for Public Regulation and Administration (CORA), University of Copenhagen, Copenhagen, Denmark

e-mail: Trine.Baumbach@jur.ku.dk

(C) The Author(s) 2019

A. Albi and S. Bardutzky (eds.), National Constitutions in European

and Global Governance: Democracy, Rights, the Rule of Law,

https://doi.org/10.1007/978-94-6265-273-6_7 
executive had implemented EU directives by administrative acts in nine out of ten cases. Other constitutional issues that have arisen include considerable debate regarding the Laval line of cases, given the strong Scandinavian welfare system and the tradition of ordinary collective agreements. Another concern that has been raised by the Danish Supreme Court is that the use of teleological interpretation in a number of ECJ cases has affected legal certainty and foreseeability, which are at the centre of the Danish understanding of the rule of law.

Keywords The Constitution of Denmark - Absence of EU amendments Difficult amendment procedure involving two referendums - Danish Supreme Court · Judicial review - ECHR - Deference of courts · Implementation of EU law by governmental regulations - Laval and impact on collective action, posted workers and the Scandinavian welfare system - European Arrest Warrant and extraditions - Data Retention Directive - Teleological interpretation, legal certainty and foreseeability of law

\section{Constitutional Amendments Regarding EU Membership}

\subsection{Constitutional Culture}

1.1.1-1.1.2 The Danish Constitution falls within the evolutionary category. The original Constitution from 1849 was influenced by the Enlightenment and French philosophers such as Montesquieu. Hence, focus was on the ideas of separation of powers and human rights. However, in Denmark it was a 'peaceful' revolution. The Danish King chose to cede power to the people, and this way Denmark changed its form of state from an absolute monarchy to a constitutional monarchy. In the first phase after the adoption of the Constitution the King still had several competences, for instance he appointed and dismissed the Government. However, this was changed, and since 1901 Denmark has had negative parliamentarianism - first as a constitutional convention and since 1953 with a legal basis (Art. 15) in the Constitution. Until 1915, many groups in society, including women, did not have the right to vote. However, in 1915 the Constitution became a 'democratic' constitution providing women, servants, people living in poverty, criminals and the mentally ill with the right to vote. While the Danish Constitution is concerned with both the organisation of the state and rights, more provisions concern the organisation of the state (institutions, competences, etc.). It is interesting that the first Articles of the Constitution concern the Danish territory, the form of government and separation of powers. Human rights are regulated in Chap. 8 of the Constitution (Arts. 71-85). The Constitution has a total of 89 provisions. 


\subsection{The Amendment of Constitutions in Relationship to the European Union}

1.2.1 The Danish Constitution has not been amended in relation to EU membership.

1.2.2 The amendment procedure in Art. 88 of the Constitution is characterised by being extensive and by involving the people twice. After Parliament has adopted an amendment bill, an election must be held. The new Parliament must adopt the same bill, and within 6 months a referendum on the bill must take place. In this referendum a majority of those voting and at least $40 \%$ of those entitled to vote must vote in favour of the bill, which takes effect upon signature by the King. It is quite difficult to change the Danish Constitution, and the requirement of $40 \%$ is especially difficult to obtain. ${ }^{1}$

\subsubsection{Not applicable.}

1.2.4 Since the Danish Constitution does not mention EU membership, the Constitution would provide the reader with a more realistic picture of the competences and allocation of powers if the EU were mentioned in the Constitution. Such a development has taken place in the other Nordic EU Member States (Sweden and Finland). Furthermore, it might be relevant to write down some of the procedures connected to national decision-making processes, for instance the existence of the European Policy Committee and the mandate procedure. Some countries such as Germany, France and Portugal have strengthened the role of the national parliament in the constitution in connection with ratification of the Lisbon Treaty. ${ }^{2}$ Denmark could consider whether this would be desirable in order to re-establish the power balance between the Parliament and the Government in light of EU cooperation. Another question which could be considered is the criteria for calling a referendum when Denmark wants to enter a new EU treaty. According to Art. 20, a referendum must be held if the accession to a treaty involves the transfer of powers granted to Danish authorities by the Constitution and fewer than five-sixths of the members of Parliament support such accession. As will be seen in Sect. 1.3.1, transfer of sovereignty is regulated in Art. 20 of the Constitution. This means that quite technical treaties such as the Amsterdam Treaty and the European Patent Convention have been subject to a referendum, whereas the Lisbon Treaty which entailed institutional changes that affected the democratic structure of the EU required no referendum. Hence, one might ask whether Art. 20 reflects the importance of the treaties, especially in the eyes of the electorate. ${ }^{3}$ These are examples of issues which could be considered in a revision of the Constitution.

\footnotetext{
${ }^{1}$ For more details on constitutional change in Denmark, see Krunke 2013, pp. 73-92.

${ }^{2}$ See for instance Piris 2010, p. 126.

${ }^{3}$ Krunke 2013, pp. 542-570, especially pp. 569-570.
} 


\subsection{Conceptualising Sovereignty and the Limits to the Transfer of Powers}

1.3.1 Two constitutional provisions regulate Denmark's participation in international cooperation:

Art. 19 Subsection 1: The King shall act on behalf of the Realm in international affairs, but, except with the consent of the Folketing [Parliament], the King shall not undertake any act whereby the territory of the Realm shall be increased or reduced, nor shall he enter into any obligation the fulfilment of which requires the concurrence of the Folketing or which is otherwise of major importance; nor shall the King, except with the consent of the Folketing, denounce any international treaty entered into with the consent of the Folketing.

Art. 20 Subsection 1: Powers vested in the authorities of the Realm under this Constitutional Act may, to such an extent as shall be provided by statute, be delegated to international authorities set up by mutual agreement with other states for the promotion of international rules of law and cooperation.

Subsection 2: For the enactment of a Bill dealing with the above, a majority of five sixths of the Members of the Folketing shall be required. If this majority is not obtained, whereas the majority required for the passing of ordinary Bills is obtained, and if the Government maintains it, the Bill shall be submitted to the electorate for approval or rejection in accordance with the rules for referendums laid down in Section $42 .{ }^{4}$

Article 20 entered the Constitution during the last revision in 1953. Inspired by the Coal and Steel Union, it was foreseen that Denmark might want to join some form of supranational cooperation in the future. By introducing Art. 20 into the Constitution it would not be necessary to amend the Constitution following the Art. 88 procedure in order to enter a supranational organisation. The procedure in Art. 20 is not as extensive as the Art. 88 procedure. Obviously, in a country with EU sceptic voters but a majority of politicians in favour of EU cooperation, there might be a political interest in entering into EU treaties through the simplest possible procedure.

1.3.2-1.3.3 Since the 1953 Constitution allows for the transfer of sovereignty to supranational organisations, the Constitution is not based on an absolute sovereignty line of thinking. The system in the Constitution is very much related to procedure: the more intense the international cooperation, the more complex a procedure must be followed to enter it. This is reflected in the degree of involvement of Parliament and the electorate in the decision-making process. If it is 'normal' international cooperation, the Art. 19 procedure will be sufficient. If sovereignty is transferred, then the Art. 20 procedure is necessary and, if the cooperation is even more intensive and the transferred competences are not specified, the Art. 88 procedure will be required. This means that the transfer of competence is primarily a question of procedure.

\footnotetext{
${ }^{4}$ All quotes from the Constitution are from the translation of the Danish Constitution at the homepage of the Danish Parliament: https://www.thedanishparliament.dk/ /media/pdf/publikationer/english/my_ constitutional_act_with_explanations.ashx.
} 
There are few limits to the extent to which powers can be delegated to the EU through the Art. 20 procedure. As mentioned, the transferred competences must be specified according to Art. 20. All legislative, executive or judicial power cannot be transferred. ${ }^{5}$ Neither can the power to change the Constitution ${ }^{6}$ nor the power to transfer sovereignty in Art. $20{ }^{7}$ The power to decide the age of voting can probably not be transferred. ${ }^{8}$ Provisions on national elections and on the competence of the Court of Impeachment are also excluded from transfer. ${ }^{9}$ Powers that are not held by any Danish authority can also not be transferred; for instance, human rights protection must be respected. ${ }^{10}$ The latter was also emphasised by the Supreme Court in the Maastricht judgment. ${ }^{11}$ It also follows from this judgment that Denmark must remain an independent state, which is a constitutional precondition for a transfer of powers under Art. 20. However, even if Denmark should want to enter a treaty which falls outside what is possible according to Art. 20, it would be possible to enter such treaty through an amendment of the Constitution. The Constitution of Denmark has no eternity clauses.

1.3.4 Denmark has a dualistic system. This can be interpreted from Art. 19 and from case law. ${ }^{12}$

The Maastricht judgment and the Lisbon judgment have contributed to the interpretation of Arts. 19 and 20. The legal question in the Maastricht judgment was whether the Art. 20 procedure was sufficient when Denmark entered into the Maastricht Treaty. The legal question in the Lisbon Judgment was whether the Art. 19 procedure was sufficient when Denmark entered into the Lisbon Treaty. As regards the question of supremacy of EU law, the Supreme Court has not accepted supremacy in relation to the Danish Constitution.

In the Lisbon case the Supreme Court stated the following: ${ }^{13}$ 'In the Maastricht judgment, the Supreme Court found, among other things, that it is for the Danish courts to decide whether EU acts exceed the limits to the surrender of sovereignty which has taken place under the Accession Act'. Paragraph 9.6 of the judgment thus reads:

9.6. ... By adopting the Accession Act, it has been recognised that the power to test the validity and legality of EC acts of law lies with the EC Court of Justice. This implies that Danish courts of law cannot hold than an EC act is inapplicable in Denmark without the

\footnotetext{
${ }^{5}$ See Zahle 2006, p. 414.

${ }^{6}$ See Zahle 2006, p. 413 and Andersen 1954, p. 497.

${ }^{7}$ See Zahle 2006, p. 413.

${ }^{8}$ Ibid.

${ }^{9}$ Ibid. For a different perspective, see Jensen and Jensen 1991.

${ }^{10}$ See Zahle 2006, pp. 413.

${ }^{11}$ See U $1998.800 \mathrm{H}$.

${ }^{12}$ See for instance Rytter 2012, p. 189, U 2006.700H, U 2010.1035 and U 2010.1547H.

${ }^{13}$ Supreme Court judgment of 20 February 2013, Case No. 199/2012, p. 15, U 2013.1451H, p. 1518. See translation of the judgment at the homepage of the Danish Supreme Court: http:// www.hoejesteret.dk/hoejesteret/nyheder/ovrigenyheder/Documents/199-12engelsk.pdf.
} 
question of its compatibility with the Treaty having been tried by the EC Court of Justice, and that Danish courts of law can generally base their decision on decisions by the Court of Justice on such questions being within the limits of the surrender of sovereignty. However, the Supreme Court finds that it follows from the demand for specification in s. 20(1) of the Constitution, held against the Danish courts' access to test the constitutionality of acts, that the courts of law cannot be deprived of their right to try questions as to whether an EC act of law exceeds the limits for surrender of sovereignty determined by the Accession Act. Therefore, Danish courts must rule that an EC act is inapplicable in Denmark if the extraordinary situation should arise that with the required certainty it can be established that an EC act which has been upheld by the EC Court of Justice is based on an application of the Treaty which lies beyond the surrender of sovereignty according to the Accession Act. Similarly, this applies with regard to community-law rules and legal principles which are based on the practice of the EC Court of Justice. [Author's italics]

The Court further stated that:

... the Court of Justice of the European Union is charged with settling any disputes on the interpretation of EU law, but this must not result in widening of the scope of Union powers. As mentioned above, Denmark's implementation of the Treaty of Lisbon was based on a constitutional assessment that it will not imply delegation of powers requiring application of the s. 20 procedure, and the Danish authorities are obliged to ensure that this is observed. ... if an act or a judicial decision which has a specific and real impact on Danish citizens etc. raises doubts as to whether it is based on an application of the Treaties which lies beyond the surrender of sovereignty according to the Accession Act, as amended, this may be made subject to a judicial review, as stated in paragraph 9.6 of the Maastricht judgment. The same applies if EU acts are adopted - or if the Court of Justice delivers judgments - based on such application of the Treaties with reference to the Charter of Fundamental Rights. [Author's italics]

In general The Supreme Court shows deference when reviewing the constitutionality of legislation. This means that the Court will only rule an Act unconstitutional if it is in clear violation of the Constitution. This practice has also been followed in relation to legislation on Denmark's accession to EU treaties.

Furthermore, Danish courts will normally try to interpret Danish legislation in conformity with EU law.

\subsection{Democratic Control}

1.4.1 The EU is not mentioned in the Constitution and neither is the role of the Parliament in the EU decision-making process. The involvement of the Danish Parliament is mentioned in the Danish Act on Accession to the EU, Art. 6, part 2, according to which the Government must inform the European Policy Committee on proposals in the Council which will have direct effect in Denmark or which will require the participation of Parliament for implementation. However, in practice Parliament has significant influence. Among others, a mandate procedure has been 
Table 1 EU related referendums

\begin{tabular}{l|l|l}
\hline $\begin{array}{l}\text { Date of } \\
\text { referendum: }\end{array}$ & Referendum concerning: & Outcome: \\
\hline $\begin{array}{l}2 \text { October } \\
1972\end{array}$ & Danish accession to the EC & $\begin{array}{l}63.4 \% \text { in } \\
\text { favour }\end{array}$ \\
\hline $\begin{array}{l}27 \text { February } \\
1986\end{array}$ & Single European Act & $\begin{array}{l}56.2 \% \text { in } \\
\text { favour }\end{array}$ \\
\hline 2 June 1992 & Maastricht Treaty & $\begin{array}{l}50.7 \% \\
\text { rejected }\end{array}$ \\
\hline $\begin{array}{l}18 \text { May } \\
1993\end{array}$ & Maastricht Treaty with Danish exceptions & $\begin{array}{l}56.7 \% \text { in } \\
\text { favour }\end{array}$ \\
\hline $\begin{array}{l}28 \text { May } \\
1998\end{array}$ & Amsterdam Treaty & $\begin{array}{l}55.2 \% \text { in } \\
\text { favour }\end{array}$ \\
\hline $\begin{array}{l}28 \\
\text { September }\end{array}$ & $\begin{array}{l}\text { Third stage of the Economic and Monetary Union (one of the } \\
\text { Danish exceptions stemming from the accession to the }\end{array}$ & $\begin{array}{l}53.2 \% \\
\text { rejected }\end{array}$ \\
\hline $\begin{array}{l}25 \text { May } \\
2014\end{array}$ & Maastricht Treaty) & $\begin{array}{l}62.5 \% \text { in } \\
\text { favour }\end{array}$ \\
\hline $\begin{array}{l}\text { 3 December } \\
2015\end{array}$ & Justice and Home Affairs Opt-Out & $\begin{array}{l}53,1 \% \\
\text { rejected }\end{array}$ \\
\hline
\end{tabular}

Source The Danish Parliament, EU Information Centre, https://english.eu.dk/en/denmark_eu/eureferenda.

established according to which the Government will not vote in favour of a proposal in the Council if a majority in the European Policy Committee is against it. ${ }^{14}$ These developments of the Committee's control over EU Policy are written down in a number of Committee reports. Hence, even though the Danish parliamentary control system is often said to be one of the strongest in Europe, it has very little formal basis in legislation and none in the Constitution. Put in very general terms, the success of the Danish European Policy Committee lies in (1) the mandate procedure, which is respected by the Government (and is considered legally binding by some legal experts whereas others only consider it politically binding on the Government), (2) the early involvement of the Committee in the decision-making process, and (3) the Government keeping the Committee updated if a proposal changes along the way in the EU decision-making process. ${ }^{15}$ One further important factor is the Danish tradition of minority Governments, which naturally strengthens Parliament.

1.4.2 Denmark has held a number of referendums on (1) accession to the EC, (2) EC/EU treaties and (3) exceptions from the treaties. These are summarised in Table 1.

\footnotetext{
${ }^{14}$ It is not possible to go into details about the control process. For more information on the Danish Parliament's control of EU Policy, see for instance Krunke 2007, pp. 335-348, and Krunke 2008-2009, pp. 105-107.

${ }^{15}$ See also Krunke 2008-2009, pp. 105-107.
} 
The most interesting referendums and certainly the best known outside Denmark are the two referendums on the Maastricht Treaty (of which the second included a number of Danish exceptions from the Treaty). ${ }^{16}$

\subsection{The Reasons for, and the Role of, EU Amendments}

\subsubsection{Not applicable.}

1.5.2 As mentioned, Denmark has not amended its Constitution in relation to the EU. One might ask why this is. In answering this, it might be useful to make a distinction between legally necessary amendments on the one hand, and amendments which are not legally necessary but driven by other purposes.

Several reasons can be given why amendments have not been legally necessary. In 1953 (i.e. the time of the last amendment of the Constitution), the Constitution was designed in such a way that it would be possible for Denmark to enter into and take part in supranational co-operation without having to amend the Constitution. According to Art. 20, powers which rest with Danish authorities can to a specific extent be transferred to an international organisation. There are few constitutional constraints on the content of Danish legislation. Therefore, there are also few constraints on the legislative competence which can be transferred according to Art. 20. Article 20 leaves some room for interpretation. Political institutions play an important role in interpreting the Constitution. The courts are traditionally careful when performing judicial review - only clear violations are viewed as violations of the Constitution.

What other potential purposes could amending the Constitution due to EU membership serve? One such purpose could be to design the Constitution such that it reflects the actual allocation of political power in the light of EU membership, and to thus formulate a Constitution which ordinary citizens can read and understand. Furthermore, there could be a desire to change the national power allocation as a result of EU membership - for instance to strengthen the national Parliament in new ways or to give constitutional effect to parliamentary control functions which already exist in political practice. Thirdly, there could be a desire to alter the provisions on transfer of sovereignty (Art. 20) in light of the experiences of the past 40 years of EU membership. For instance, as mentioned above, one might ask whether Art. 20 reflects what is important to the citizens. In which situations should a referendum be held? Or is the provision clear enough? Finally, one purpose could be to strengthen/renew the democratic legitimacy of the Constitution through a constitutional revision process which involves the electorate (the last time the electorate voted on the content of the Constitution was in 1953).

Given these purposes, why have such amendments not been made? Several reasons can be given. To date, no political majority has been in favour of a general

\footnotetext{
${ }^{16}$ Krunke 2005, pp. 339-356.
} 
revision. Such a revision would naturally initiate a debate on possible provisions on EU membership. Another reason is the complicated amendment procedure in Art. 88 , in which the electorate must be involved twice (election and referendum). Thirdly, Art. 20 functions in practice, and it might be difficult to design a legally better functioning provision (only a different provision). Fourthly, reasons of a more political nature probably exist. Quite a far-reaching transfer of power is possible under Art. 20 (also without involving the electorate) - a large majority of politicians have thus far been in favour of Danish EU membership. As regards a general revision of the Constitution, this would raise public and political debate over a number of sensitive political questions. Fifthly, there has not been enough pressure from the electorate and/or a majority in Parliament for more influence on EU-matters in the Constitution. Finally, Denmark has a tradition of strong parliamentary involvement in EU affairs (mandate procedure, etc.) and minority Governments.

According to Hjalte Rasmussen, the absence of EU amendments in the Constitution has even resulted in a process of 'waning constitutionalism'. He states that the Constitution has been fossilised and marginalised 'because of the unavailability of any real amendment procedure, coupled with the application of judicial hands-off policy which precludes alternative routes to the document becoming a centrepiece of a living constitutionalism, as well as the absence of a constitutional theory'; as a result of this, 'the constitutional limits to transfers of sovereignty have turned into rules that provide for a political essential discretionary assessment' ${ }^{17}$ On the one hand, it is probably true that the Supreme Court could in some cases have interpreted Art. 20 in a less restrictive manner, leaving less room for the political institutions' interpretation of Art. 20 while still staying within the limits of a traditional constitutional interpretation of the provision. ${ }^{18}$ However, on the other hand, the Supreme Court is in general traditionally careful when interpreting the Constitution and leaves much room for the political institutions' interpretation of the Constitution.

1.5.3 In the context of enhanced EU cooperation and international cooperation in general, the national constitutions have played an important role in safeguarding democratic participation and decision-making as regards this cooperation. As regards many constitutions which are not often amended, it might be worth considering whether the electorate and/or the Parliament should have an increased role in relation to EU cooperation and other international cooperation. The institutional balance between the national institutions has been drastically pushed in many

\footnotetext{
${ }^{17}$ Rasmussen 2008, p. 155.

${ }^{18}$ In relation to the Danish Lisbon judgment, see Krunke 114b, pp. 542-570. As shown in the case note, it would have been possible for the Supreme Court to interpret Art. 20 in a less restrictive way, leaving less room for the political institutions' interpretation of the provision. This was actually done by the High Court in its Lisbon judgment. However, even if this had been done, the Danish Lisbon judgment would not (necessarily) have had another outcome since a less restrictive interpretation of Art. 20 would not necessarily have resulted in the finding of a violation of Art. 20 in the case.
} 
Member States as a result of the ever closer EU and international cooperation. Such co-operation is not a negative thing - in fact it can help solve many global problems. However, it is important to secure as much democratic participation and decision-making as possible. The national constitutions can also play an important role in relation to defining a nation's constitutional identity, values and rights. As we shall return to later, constitutional dialogue between national institutions and EU institutions, for instance dialogue between national courts and the Court of Justice of the European Union (CJEU), requires a clear notion of national constitutional identity and a clear way of communicating it. Although some courts contribute to such a definition and communication of national constitutional identity, a broad debate in society on national identity, values and rights is also important. No one could have foreseen such a development in globalisation, and national constitutions need to be adjusted to fit this new reality as regards democratic, institutional and rights perspectives. In some countries - such as Denmark - the need for a strengthening/renewal of the democratic legitimacy of the Constitution through public debate and a new Constitution based on this debate seem unavoidable in light of the changed globalised reality. Some specific potential areas for amendment are outlined in Sect. 1.2.4.

\section{Constitutional Rights, the Rule of Law and EU Law}

\subsection{The Position of Constitutional Rights and the Rule of Law in the Constitution}

2.1.1 Human rights are regulated in Chaps. 7 and 8 of the Danish Constitution. The Constitution protects the traditional political freedoms: freedom of speech (Art. 77), freedom of association (Art. 78) and freedom of assembly (Art. 79). Furthermore, classical rights such as the right to property (Art. 73), the right to personal liberty (Art. 71), the right to privacy (Art. 72) and freedom of religion (Arts. 67, 68 and 70) are protected. The Constitution protects certain social rights (Arts. 75 and 76). Finally, some provisions outside the chapters on protection of human rights should be mentioned. The Constitution has no provision on the right to a fair trial. However, according to Arts. 3 and 64 the courts are independent, and according to Art. 63, the courts can review administrative decisions. According to Art. 65 the administration of justice must be public and oral. The human rights catalogue is old and not very comprehensive according to a modern standard. The protection provided by the European Convention on Human Rights (ECHR) has become increasingly important, and in many cases the Convention and the practice of the European Court of Human Rights (ECtHR) go further in protecting human rights than the Constitution.

In general, the provisions on human rights in the Constitution are enforceable in courts. Only in a few cases has the general assumption been that part of a provision 
is so general that it does not contain an independent legal content/right which could be enforced in courts. One example is the first sentence of the provision on the right to property in Art. 73, '[o]wnership is inviolable'. However, it should be mentioned that part of the legal literature does not agree with the general assumption that Art. 73, part 1, first sentence, is not enforceable, and at least one judgment seems to support such an interpretation. ${ }^{19}$ Another example is part 2 of the provision on protection of social rights in Art. 75, which provides that '[a] person who is unable to support himself or his dependents, and whom no one else is under an obligation to support, is entitled to assistance from the State, while accepting the obligations that the Act relating to such assistance imposes.' However, in a ground-breaking judgment from $2006,{ }^{20}$ the Supreme Court introduced that a private party could invoke a right based directly on Art. 75, part 2 (and not only on rights according to social legislation). This means that Art. 75, part 2 is now enforceable in courts.

Denmark does not have a strong tradition of codifying general principles of law in the Constitution. The general principles of law are often unwritten principles which are enforced by the courts and mentioned in legal literature and/or underlying considerations, presumptions and values which implicitly lie behind constitutional and legislative provisions. Danish courts have a rather pragmatic approach, which means that they often apply legal principles without making direct references to them and without specifying whether the principles have constitutional rank. All of these factors contribute to a somewhat unclear picture of which legal principles exist and whether they have constitutional rank. In general, the unclear character of a 'legal principle' as an independent legal source or a source of interpretation obviously adds to this picture.

The principle of legitimate expectations is not explicitly codified in the Constitution. Nevertheless, a protection of legitimate expectations is indirectly reflected in for instance the provision on protection of property in Art. 73. In the case law, legitimate expectations are often used as legal arguments in relation to Art. $73 .^{21}$ In at least one case from the High Court legitimate expectations have been treated as an independent source of law. ${ }^{22}$ This seems to support the idea of a general constitutional principle of legitimate expectations with constitutional rank. $^{23}$

The principle of equality as an abstract norm is not codified in the Constitution. Nevertheless, the protection of equality is reflected in a number of specific constitutional provisions, for instance Art. 70 on protection against discrimination

\footnotetext{
${ }^{19}$ Berlin 1939, pp. 388-390; Larsen 1940, p. 60; Ross 1966, p. 665; Krunke 2010, pp. 211-223. See also U 1958.595H.

${ }^{20} \mathrm{U} 2006.770 \mathrm{H}$.

${ }^{21}$ Krunke 2010, pp. 101-117. On legitimate expectations see also UfR 2011, p. 1365 and Mørup 2005.

${ }^{22}$ Unpublished judgment from the High Court of 24 June 2004 (B-1626-01).

${ }^{23}$ Krunke 2010, pp. 106-107 and 115-117.
} 
based on religion or origin in relation to civil and political rights. The case law is not clear in this field. ${ }^{24}$

The principle of proportionality is not codified in the Constitution. However, according to legal theory the principle of proportionality must be interpreted together with constitutional rights provisions when possible. ${ }^{25}$ One might say that the principle thus indirectly gains constitutional rank at least in relation to a number of rights (see below Sect. 2.1.2).

The definition of the concept of legal certainty is not entirely clear. ${ }^{26}$ A very general definition would emphasise that (1) legal certainty concerns the relationship between the individual and the authorities, (2) that the individual must not be subject to arbitrary abuse of power and (3) that the state of the law must be predictable for the individual. ${ }^{27}$ However, a broader definition could include the legislative process and the content of legislation including respect of fundamental rights. ${ }^{28}$ Neither is the distinction between the principle of legal certainty and the principle of the rule of law clear. A recent attempt to identify the content of the two principles emphasises that the principle of legal certainty has the personal freedom of the individual, including the rights of minorities, as its main focus, while the principle of the rule of law has the separation of powers and the legality of the administration as its main focus. Furthermore, it has been stated that the rule of law is a precondition for legal certainty, and legal certainty legitimises the rule of law. ${ }^{29}$ At the FIDE congress in 2014, the then Danish Supreme Court President, Børge Dahl, stated the following on the principles of the rule of law and legal certainty:

The concept of the rule of law implies a number of things. One aspect is the principle of equality before the law. Another aspect is the principle of legal certainty: Without legal certainty there can be no rule of law.

In its strictest sense, legal certainty means the elimination of arbitrariness. This again implies that the courts must act in a way that makes it possible for the citizens to plan their activities and foresee the legal consequences of their actions. In this regard, the principle of legal certainty is synonymous with a minimum degree of clarity and foreseeability in the legal system. ${ }^{30}$

The Constitution does not have a general provision on protection of legal certainty. Nevertheless, the principle of legal certainty and the principle of the rule of law are reflected in a number of more specific provisions in the Constitution: Art. 3 on separation of powers; Art. 22 on promulgation; Art. 43 according to which taxes

\footnotetext{
${ }^{24}$ Two interesting judgments which perhaps support the existence of a general principle of equality are U $1960.33 \mathrm{H}$ and $\mathrm{U} 1989.148 / 2 \mathrm{H}$.

25 Jensen 1994, p. 335.

${ }^{26}$ Henrichsen 1997, Chap. 1. For instance legal certainty can be seen from an administrative law point of view or from a constitutional law point of view.

${ }^{27}$ See Henrichsen 1997, pp. 83-84.

${ }^{28}$ Ibid., p. 63.

${ }^{29}$ See Dansk Center for Menneskerettigheder og Advokatsamfundet 2012, p. 7.

${ }^{30}$ See Dahl 2014, p. 27.
} 
must have a legal basis in an Act; Art. 62 according to which the courts must be independent of the Government and the public administration; Art. 63 on review of administrative decisions; Art. 64 according to which judges shall be governed solely by the law; Art. 65 according to which all proceedings shall to the widest possible extent be public and oral in the administration of justice; protection of personal liberty in Art. 71; the right to privacy in Art. 72; and the political freedoms set out in Arts. 77-79.

Furthermore, legal certainty is applied and sometimes referred to in case law. However, often it is not clear whether the principle is applied as a source of interpretation when interpreting legislation or whether it is applied as an independent source of law. Furthermore, it is not clear whether the principle has constitutional rank. However, a number of particularly interesting judgments which might indicate the existence of an independent principle of legal certainty and a rank above normal legislation will be mentioned here.

Two judgments from the past decade seem to indicate that not only does a principle of legal certainty exist but it also has a higher rank than normal legislation. The Supreme Court has ruled that a video tape containing an examination of a child could not be played during the trial against her foster father who was accused of abusing her sexually. ${ }^{31}$ Although such evidence was normally allowed according to the Administration of Justice Act, Art. 877, part 3, the Supreme Court would not allow it based on considerations of legal certainty. The reason was, among other factors, that the defendant had not been able to consult with his defence lawyer before the examination of the child or to view the video tape afterwards together with his defence lawyer.

In the second judgment it becomes even more clear that the rank of the principle of legal certainty is higher than that of normal legislation. The case concerned a Tunisian citizen who had planned to kill one of the so-called Muhammad cartoonists. Based on the Danish Aliens Act the Danish Immigration Service decided to permanently deport him because he was a danger to the state, ${ }^{32}$ and the police detained him. According to Art. 37, the courts can review the legality of such a detention. The Supreme Court stated that the review of such detention must include at least some review of the factual foundation that determines whether a foreign citizen must be considered a danger to the state. The authorities must make this possible by submitting sufficient documentation in court with the possibility for the defendant to raise objections.

In recent case law, the Supreme Court has expressed concern whether certain interpretations of EU law by the European Court of Justice have violated legal certainty. This was clear in a case from 2014 in which the Supreme Court determined whether the employer or the employee should carry the risk of the employee becoming sick during his vacation. ${ }^{33}$

\footnotetext{
${ }^{31}$ See U 2000.1751H.

${ }^{32}$ See U 2008.2394H.

${ }^{33}$ See U 2014.914H.
} 
In other words, can an employee request a new vacation period for the days he was ill? The Danish Holidays Act from 2000 was very precise on this matter, leaving the risk to the employee. The legal question was whether it was possible to interpret the Act in accordance with Directive 2003/88 ${ }^{34}$ and thereby in such a way that the employer should carry the risk. The Supreme Court stated that the duty to interpret national law in accordance with EU law does not apply if this would violate general principles of law such as the principle of legal certainty and non-retroactivity. Neither does this duty apply if this would lead to a contra legem interpretation of national law. The Supreme Court concluded that according to the Danish legal principles of interpretation, it was not possible to interpret the Danish Act in compliance with Directive 2003/88. This would be contra legem, which the EU principle regarding the duty to interpret national law in accordance with EU law does not require. According to the Supreme Court, such an interpretation would also constitute a violation of legal certainty and predictability which must be required when applying the law in relation to the Holidays Act from 2000 with regard to the employer. When the Supreme Court refers to legal certainty, it is not entirely clear whether it refers to it as a legal principle in EU law and/or in Danish law. The exception from the duty to interpret national law in conformity with EU law is related to the general principles of EU law. ${ }^{35}$

Another example is a Supreme Court decision from $2014,{ }^{36}$ in which the Supreme Court decided to request a preliminary ruling from the CJEU in a case on age discrimination. The main question was whether an unwritten EU principle prohibiting age discrimination must prevail over a contradictory written provision in national legislation which provides a private party with a legal basis to not pay severance pay. In the preliminary questions to the CJEU, the Danish Supreme Court referred to the principle of legal certainty and the related principle of legitimate expectations. The Supreme Court asked whether it would be in accordance with EU law if the Supreme Court ruled that the principle of legal certainty must prevail over the unwritten EU principle of the prohibition against age discrimination. The latter two cases also relate to the rule of law (see below Sect. 2.1.3).

Finally, there are some Acts which provide for legal certainty in specific areas such as social policy and the administrative use of force. ${ }^{37}$ In conclusion, legal certainty is without doubt a Danish legal principle, and the case law described above seems to support that the principle has a higher rank than does normal legislation (see for instance U 2008.2394H). This points in the direction of a constitutional principle with constitutional rank.

As regards the principle of the rule of law, see below in Sect. 2.1.3.

\footnotetext{
${ }^{34}$ Directive 2003/88/EC of the European Parliament and of the Council of 4 November 2003 concerning certain aspects of the organisation of working time, [2003] OJ L 299/9.

${ }^{35}$ Case C-80/86 Kolpinghuis Nijmegen [1987] ECR 03969, para. 13.

${ }^{36}$ Supreme Court decision of 22 September 2014, case 15/2014, 1. Afdeling.

${ }^{37}$ See LBK nr. 983 af 08/08/2013 and Lov nr. 442 af 09/06/2004.
} 
A democratic form of government is an underlying value which is reflected in a number of articles, for instance on the right to vote in elections and referendums and political freedoms. In U $1999.1798 \mathrm{H}$, the Supreme Court, borrowing from the wording of the case law of the ECtHR but relating them to the Danish Constitution, stated that freedom of speech (Art. 77), freedom of association (Art. 78) and freedom of assembly (Art. of 79) are necessary and natural preconditions for democracy. The Danish judgment on the Maastricht Treaty seems to accept the existence of a constitutional presumption of a democratic form of government. ${ }^{38}$ Hence, one could argue that a democratic form of government is a legal principle at constitutional level.

2.1.2 Although the Danish Constitution does not have a general provision stipulating the conditions under which restrictions can be imposed on rights, the specific provisions in Arts. 67, 73 and 77-79 on particular rights do. For example, Art. 73 expressly states that restrictions can only be imposed by statute. However, this also follows from the unwritten principle of legality. ${ }^{39}$ Therefore, restrictions under all of the mentioned articles require a legal basis in a statute. Furthermore, as mentioned, the principle of proportionality must be interpreted together with constitutional rights provisions where possible. ${ }^{40}$ This means that imposed restrictions on (as a minimum) the rights described in Arts. 67, 70, 73 and 77-79 must be proportional. ${ }^{41}$ Finally, an imposed restriction must have a legitimate purpose. Such purpose must follow from the specific rights provisions. ${ }^{42}$ For instance according to Art. 67, an imposed restriction on the freedom of religion must be required by decency and public order; according to Art. 73, an imposed restriction on the right to property must be required by the common good. These requirements of a legal basis set out in a statute, proportionality and a legitimate purpose are supported by the case law of the Danish courts. Of particular interest is the Supreme Court case mentioned above on restrictions on the freedom of assembly, since the Supreme Court when interpreting Art. 79 of the Constitution, borrowing the wording of the case law of the ECtHR but relating them to the Danish Constitution, has stated that freedom of speech (Art. 77), freedom of association (Art. 78) and freedom of assembly (Art. of 79) are necessary and natural preconditions for democracy. ${ }^{43}$

2.1.3 The English definition of the principle of the rule of law is not entirely clear and neither is the Danish concept of the rule of law. Furthermore, the principle of the rule of law has slightly different meanings in different legal systems. ${ }^{44}$

\footnotetext{
${ }^{38} \mathrm{U} 1998.800 \mathrm{H}$.

${ }^{39}$ Rytter 2012, p.117.

40 Jensen 1994, p. 335.

${ }^{41}$ Rytter 2012, p. 112.

42 Ibid., p. 123.

${ }^{43}$ See U $1999.1798 \mathrm{H}$.

${ }^{44}$ See for instance Koch 2008, pp. 45-63. Koch among others compares the notion 'rule of law' in the English and German legal systems.
} 
The principle of the rule of law is not mentioned as a legal principle in the Danish Constitution. However, as noted in Sect. 2.1.1, several provisions in the Constitution and the unwritten principle of legality must be said to create the rule of law, although it is not possible to make a clear distinction between which constitutional provisions protect the rule of law and which protect legal certainty. Provisions such as separation of powers (Art. 3), independence of the courts (including that judges shall be governed solely by the law (Art. 64)) and judicial review of administrative decisions (Art. 63) all support the rule of law. The rule of law is furthermore ensured by judicial review of legislation by the courts. This competence of the courts is not written in the Constitution. However, it is considered to be a legal rule at constitutional level. The principle of legality is an unwritten principle which expresses a cornerstone in the protection of the rule of law.

In the contemporary literature on constitutional law, the principle of the rule of law is directly mentioned with regard to the following provisions: Art. 62 of the Constitution according to which the administration of justice must be kept separate from public administration; Art. 63 on judicial review of administrative decisions; Art. 64 regarding the independence of the courts from the Government; Art. 55 regarding the Ombudsman's control of public administration; constitutional provisions on human rights from which duties for the authorities, such as regarding administrative decisions, can be derived; and finally the rule of law is mentioned as regards the unwritten principle of legality. ${ }^{45}$

A search for the 'principle of the rule of law' in Danish case law shows that the rule of law is not a frequently used term. The 'principle of the rule of law' only appears in 11 judgments, and in some of them the concept appears in reference to the European Charter of Human Rights or EU legislation and EU judgments. ${ }^{46}$

In U $1961.1085 \varnothing$ the relatives of a man who was executed during the Second World War wanted to read the authorities' files on the case. Their lawyer argued that it follows from the principle of the rule of law (and legislation) that there must be the greatest possible access to public decisions. In U $2009.426 \mathrm{H}$ a defence lawyer argued that in a society built on the rule of law, the evidence in that case could not lead to such a radical measure as detention. In U 2012.2874H the defendant, a ministry, argued that the legislation that prescribed compulsory attendance in a refugee camp did not violate the principle of the rule of law. In VL 2007B-1135-05 the principle of the rule of law was invoked by the plaintiff, a Danish citizen, in the Danish National Tax Tribunal but not in the High Court. However, the High Court judgment provides a summary of the proceedings in the Danish National Tax Tribunal.

\footnotetext{
${ }^{45}$ Zahle 2006, pp. 222 and 227, and Zahle 2001, p. 36.

${ }^{46}$ See U 2013.834H (as regards TEU Art. 6) and U 2013.1451H (as regards TEU Art. 10B). In OE2012.S-3494-11 the lower court's decision is mentioned, and the court states that the demand for a clear legal basis in criminal law cases must 'not least be seen in the light of the impact of the ECHR as regards the protection of the fundamental principles of the rule of law'.
} 
In five judgments, the 'principle of the rule of law' appears to concern the Danish terrorism provision in the Danish Criminal Act (Art. 114). ${ }^{47}$ According to the travaux préparatoires, this provision must be interpreted in light of the EU framework decision on the fight against terrorism. ${ }^{48}$ The Framework Decision refers to actions aimed as a threat against the democratic society which respects the principle of the rule of law. Thus, the plaintiffs and the defendants in the Danish judgments regarding Art. 114 have referred to the principle of the rule of law several times. As regards the Danish terrorism provision, it is also interesting that the Danish Parliamentary Committee on Judicial Matters has expressed that 'a legitimate state builds on the principle of democracy and the principle of the rule of law'. 49

As a sub-conclusion, many applicants (private parties as well as public authorities) have presented arguments based on the principle of the rule of law in the courts.

The courts do not refer directly to this principle very often. In U 2009.1453H, the Supreme Court did so based on the fact that the travaux préparatoires for Art. 114 in the Danish Criminal Act refer to the principle of the rule of law. In TfK 2013.115OE, the lower court referred to the impact of the European Convention on Human Rights on the fundamental principles of the rule of law including that criminal liability must be predictable for the citizens. U 2014.914H and Supreme Court decision of 22 September 2014 (Sag 15/2014, 1. Afdeling) concerning a request for a preliminary ruling from the CJEU (referred to above in relation to the principle of legal certainty) also support the conclusion that the Danish Supreme Court defends the principle of the rule of law in relation to the effect of EU law in national law. At the FIDE Congress 2014, the former President of the Danish Supreme Court, Børge Dahl, referred to U 2014.914H as an example of how dynamic judgments from the CJEU violate the rule of law and the principle of legal certainty. He further stated:

I have to admit that over the years the development of law through the practice of the European Court of Justice have (sic) gone beyond the limitations drawn by the notion of legal foreseeability and certainty under Danish law. Time and again, we are confronted with European judgments finding European harmonisation to have gone further than our legislator and courts had thought. Time and again, we find ourselves bound by EU law through European judgments beyond our understanding and expectations at the time of our commitment. Time and again, I find it rather difficult to foresee the decisions made by my honourable colleagues in Luxembourg. And I know from talks with fellow justices from various countries that this is a matter of growing concern in the supreme courts of the Member States. ${ }^{50}$

\footnotetext{
${ }^{47}$ See U 2008.2394H, U 2009.426H, U 2009.1453H, U 2012.256H and U 2014.1540H.

${ }^{48}$ Council Framework Decision 2002/475/JHA of 13 June 2002 on combating terrorism, [2002] OJ L 164/3.

${ }^{49}$ See Folketingstidende 2001-2002, 2. saml., L 35, tillæg B, p. $1466 f$.

${ }^{50}$ Dahl 2014, pp. 28.
} 
The principle of the rule of law exists in Danish law, but its content is not entirely clear; furthermore the principle of the rule of law is related to the principle of legal certainty. Case law shows that the principle is normally invoked in criminal law cases either as an argument that the evidence is not clear enough or as an argument that the chosen measure is too radical. The principle has also been used as an argument in favour of public access to documents. Furthermore, the principle is referred to when it is clear that a legislative provision is based on arguments relating to the rule of law. Finally and importantly, case law from 2014 shows that the Supreme Court has recently focused on the principles of legal certainty and the rule of law in cases which concern the impact of EU law on contradictory national written law. As was the case with the principle of legal certainty, the principle of the rule of law must probably be viewed as a constitutional principle. Furthermore, it is probably at constitutional level since the Supreme Court in recent case law based its reasoning on this principle in determining that EU law should not prevail over a national legislative Act.

\title{
2.2 The Balancing of Fundamental Rights and Economic Freedoms in EU Law
}

2.2.1 The Danish report on 'The Protection of Fundamental Rights Post-Lisbon' in the FIDE 2012 proceedings expresses no concern as regards the balancing of fundamental rights and economic freedoms in EU law after Omega ${ }^{51}$ and Schmidberger: ${ }^{52}$

\begin{abstract}
It has been an ongoing concern whether the ECJ would give sufficient weight to classic fundamental rights (freedoms) whenever those rights collide with EU economic freedoms, since the latter are regarded as fundamental under EU law. This concern would generally seem to be unjustified, at least today, considering the vigour with which the ECJ is (now) upholding classic rights such as those protected by the ECHR, even when this means restricting free movement in the EU. ${ }^{53}$
\end{abstract}

The report refers to Omega and Schmidberger and later to the EU Charter:

The now legally binding EU Charter further underscores the need for the ECJ to keep giving due weight to classic freedoms in collision with economic interests, cf. Art. 52(3) EUC on EUC rights having the 'same meaning and scope' as parallel Convention rights. ${ }^{54}$

However, in the Scandinavian countries with their strong welfare systems and tradition for ordinary collective agreements (instead of legislation), cases such as

\footnotetext{
${ }^{51}$ Case C-36/02 Omega [2004] ECR I-9609.

${ }^{52}$ Case C-112/00 Schmidberger [2003] ECR I-05659.

${ }^{53}$ Lauta and Rytter 2012, p. 404.

${ }^{54}$ Ibid.
} 
Laval $^{55}$ have given rise to much debate. The Danish Government and Parliament have interpreted Laval as only requiring transparency in the way access to the Danish labour market is hindered but not as preventing Denmark from upholding its way of fixing minimum wages. ${ }^{56}$ Following Laval, a new provision on the right to take collective action in respect of posted workers was added to the Danish Posted Workers Act. ${ }^{57}$ A case similar in many ways to the Laval case was heard by the Danish Labour Court in 2005; however, the Court did not refer the case to the Court of Justice. ${ }^{58}$ In the Danish context it is interesting that many of the Danish welfare rights are protected either by normal legislation or by ordinary collective agreements as regards labour rights and thus not directly in the text of the Constitution.

\subsection{Constitutional Rights, the European Arrest Warrant and EU Criminal Law}

By way of introductory remarks, it has to be noted that Denmark has a so-called justice 'opt-out' regarding the police and judicial co-operation in criminal matters that goes back to the Edinburgh Agreement (1992). ${ }^{59}$ The opt-out forms part of the Lisbon Treaty in the sense that it is confirmed in the Protocol on the Position of Denmark, which is linked to the Lisbon Treaty as an annex. As a result of the Danish justice opt-outs, Denmark does not participate in the Council's adoption of measures proposed under Title V, Part Three of the TFEU, and none of the measures adopted under the above-mentioned provisions are binding on or apply to Denmark. $^{60}$

This means, for example, that any future directives on provisional legal aid for suspects or accused persons deprived of liberty and legal aid in European arrest warrant proceedings ${ }^{61}$ or on the strengthening of certain aspects of the presumption of innocence and of the right to be present at trial in criminal proceedings ${ }^{62}$ will not be binding on or apply to Denmark.

\footnotetext{
${ }^{55}$ Case C-341/05 Laval [2007] ECR I-11767.

${ }^{56}$ Neergaard and Nielsen 2010, p. 90.

${ }^{57}$ See Kristiansen 2013, p. 111. Neergaard and Nielsen 2010, pp. 48.

${ }^{58}$ See A 2005.839.

59 The Edinburgh Agreement granted Denmark four exceptions to the Maastricht Treaty.

${ }^{60}$ Cf. Arts. 1 and 2 of the Protocol on the position of Denmark. With the Lisbon Treaty, Denmark was given the opportunity to replace its existing justice opt-out with an opt-in scheme (like that of the United Kingdom and Ireland), cf. Art. 8 of the Protocol.

${ }^{61}$ See further Proposal for a Directive of the European Parliament and of the Council on provisional legal aid for suspects or accused persons deprived of liberty and legal aid in European arrest warrant proceedings (COM (2013) 824 final).

${ }^{62}$ See further Proposal for a Directive of the European Parliament and of the Council on the strengthening of certain aspects of the presumption of innocence and of the right to be present at trail in criminal proceedings (COM (2013) 821 final).
} 
Even though the EU acts adopted before the entry into force of the Lisbon Treaty under the then-applicable Title VI of the TEU still remain binding on and apply unchanged in Denmark on an intergovernmental basis, ${ }^{63}$ Denmark does not in principle have the option to participate in the further development of this cooperation, including any future acts superseding or amending applicable acts within the area. $^{64}$

In some cases, where a new directive only regards, for instance, a more stringent criminal law regulation, Denmark is free to align its legislation with the other EU Member States in accordance with the provisions of the directive. If the new directive supersedes a specific framework decision, it is a prerequisite that the amended legislation still meet the obligations of the framework decision.

However, in those cases where a directive builds on the principle of mutual recognition, it is not possible for Denmark to transpose the directive into Danish legislation unilaterally. In these cases, potential Danish participation in the directive requires an intergovernmental agreement - a so-called parallel agreement - between Denmark and the European Community. Whether such an agreement is possible, is not clear, since the Commission is very restrictive. ${ }^{65}$

\subsubsection{The Presumption of Innocence}

2.3.1.1 In order to reply to the questions regarding the presumption of innocence, it is necessary to take the principle of mutual recognition as a judicial phenomenon as a starting point and to bear in mind that the principle is regarded as the cornerstone of judicial co-operation within the Union. The principle is based on confidence and trust among Member States that both the substantial criminal law and the administration of justice throughout the Union are built on the same level of protection and the same respect for the rule of law - including the obligation to respect fundamental rights and fundamental legal principles, as also explicitly stated in Art. 1(3) of the Framework Decision. ${ }^{66,67}$

A European arrest warrant is a judicial decision issued by a Member State with a view to accomplish the arrest and surrender by another Member State of a requested person, for the purposes of conducting a criminal prosecution or executing a

\footnotetext{
${ }^{63}$ Cf. Art. 2 of the Protocol on the position of Denmark.

${ }^{64}$ See further Baumbach 2013, pp. 300 et seq.

${ }^{65}$ See for instance the Commission's very restrictive policy in this field COM (2005) 145 def and COM (2005) 146 def where the Commission, among other things, states that a parallel agreement solution 'would have to be of an exceptional nature and apply for a transitional period only'.

${ }^{66}$ Council Framework Decision of 13 June 2002 on the European arrest warrant and the surrender procedures between Member States (2002/584/JHA), [2002] OJ L 190/1.

${ }^{67}$ See further Vestergaard and Tranberg 2012, pp. 309 et seq. and Vestergaard and Adamo 2008, pp. 147 et seq.
} 
custodial sentence or detention order. Regarding the presumption of innocence, only the first purpose is of interest.

The principle of presumption of innocence neither follows from the Danish Constitution nor from the Danish Administration of Justice Act. The principle is, however, considered a common legal principle as it is acknowledged in Art. 48 of the Charter of Fundamental Rights of the European Union and Art. 6(2) in the European Convention on Human Rights.

In this regard - and as a principle inherent in the principle of the presumption of innocence - the Danish legal system recognises the principle of in dubio pro reo as a common legal principle. Likewise, the principle that the burden of proof rests with the prosecution is determined by implication by Art. 96 of the Danish Administration of Justice Act. The Danish legal system also recognises, in Art. 752 of the Danish Administration of Justice Act, the privilege against self-incrimination as recognised by the European Court of Human Rights as a standard inherent in Art. 6 of the European Convention on Human Rights.

The Danish Ministry of Justice is the competent executing judicial authority in Denmark. If the Ministry of Justice decides to extradite the person in question, the person has the right to demand that the police bring the case to court in order to have the court determine the legality of the decision.

2.3.1.2 Neither the Ministry of Justice nor the Danish Courts are seen to review cases brought before them in the light of the principle of the presumption of innocence. On the contrary, it is underlined that the competent judicial authorities are distinctly not supposed to review the evidence or to thereby themselves rule on the assumed perpetrator's guilt. That is for the issuing Member State's judicial authority to do. This was explicitly ascertained in a Danish Western High Court decision of 13 September 2005.

In this case the Lithuanian authorities had issued a European arrest warrant to have a Danish citizen extradited for the purposes of conducting a criminal prosecution against him concerning five criminal offences. The case did not concern offences enumerated in the positive list of the Framework Decision on the European Arrest Warrant and thereby not the positive list in the Danish Act on Extradition of Offenders. ${ }^{68}$ Because of this, the principle of double criminality had to be applied. Three of the offences stated in the arrest warrant were not considered to be offences in Denmark, and extradition was therefore not possible with regard to these offences. Regarding the two offences that could form the basis of an extradition of the requested person since they were also criminal offences in Denmark, the Western High Court underlined that that Danish judicial authorities, including the court itself, were not called upon to review the evidence.

On the other hand, the Danish judicial authorities in this field are extremely particular in their rulings regarding the conditions for extradition. This is for

\footnotetext{
${ }^{68}$ The Act implements the positive list of the Framework Decision on the European Arrest Warrant in its exact wording. See further below Sect. 2.3.2 on nullum crimen, nulla poena sine lege.
} 
instance evident in the aforementioned decision of the Western High Court regarding the double criminality requirement (the case did not regard offences from the positive list). This was also seen in the Supreme Court of Denmark's decision of 17 December 2012 where the Ministry of Justice, the municipal court and the Eastern High Court's decisions were repealed and the case remitted to the Ministry of Justice, since there was not enough information provided to establish whether the prohibition of ne bis in idem represented an obstacle for extradition. These rulings did not concern consideration of evidence or therefore the question of guilt, but did, however, concern legal questions closely linked to the question of guilt.

The overall assessment with regard to the principle of the presumption of innocence is that since adherence to the principle is primarily an issue in the main hearing of the case, it is not for the preliminary judicial authorities to rule on the evidence - especially not since the Framework Decision on the European Arrest Warrant is built on the principle of mutual trust. In other words, the Danish judicial authorities seem to have the appropriate trust, and since no cases have been launched by any member of the public that might dare to raise the question of trust, the non-observance of the principle of the presumption of innocence at the arrest warrant stage has not given rise to substantial considerations in legal theory or elsewhere.

\subsubsection{Nullum crimen, nulla poena sine lege}

2.3.2.1 The principle of legality does not follow from the Danish Constitution, but the principle is codified in Art. 1 of the Danish Criminal Code backed by a common legal principle regarding the prohibition of retroactivity in criminal law to the disadvantage of the accused, as set out in Art. 49 of the Charter of Fundamental Rights of the European Union and Art. 7 of the European Convention on Human Rights. ${ }^{69}$

As can be seen from the CJEU judgment (Case C-303/05), the actual definition of the offences set out in Art. 2(2) of the Framework Decision and the penalties applicable are those which follow from the law of the issuing Member State, which, as stated above, must respect fundamental rights and legal principles, among them the principle of legality of criminal offences and penalties (nullum crimen, nulla poena sine lege). ${ }^{70}$

The departure from the rule of double criminality in cases covered by the positive list gave rise to some principled objections on the political level when the Framework Decision was to be implemented in Danish law. In the preparatory work to the Danish Act on Extradition of Offenders that implemented the Framework Decision on the European Arrest Warrant (Art. 2(2) of the Framework Decision), the departure was justified as follows:

\footnotetext{
${ }^{69}$ See further Baumbach 2011, pp. 125 et seq.

${ }^{70}$ Case C-303/05 Advocaten voor de Wereld [2007] ECR I-03633, paras. 52-53.
} 
A number of the offences included in the positive list are covered by EU instruments and require Member States to criminalise further enumerated offences. Furthermore, the European Council, in a statement in relation to the Framework Decision indicated that the Council has agreed in accordance with TEU Art. 31e, to continue to work on the approximation of the definitions of the offences covered by Art. 2(2) of the Framework Decision, in order to seek to achieve the same legal understanding among the Member States. Moreover, the Council statement contains qualifying remarks which more specifically defines what is meant by, inter alia, sabotage, extortion, racism and xenophobia.

Since the offences covered by the positive list, as a starting point, would be punishable in all Member States, the importance of the Framework Decision on this point is in particular that the requesting Member State shall not carry out a thorough check of whether the offence is also punishable in the executing State. ${ }^{71}$

The departure from the rule of double criminality has not subsequently given rise to any theoretical concerns. Presumably, this is to some extent due to the fact that the Danish Act on Extradition of Offenders, in accordance with the optional rule in Art. 4(7) letter a of the Framework Decision, has a special legal provision (Art. $10 \mathrm{f}$ (1)) that determines as a mandatory rule that extradition cannot take place if the relevant act wholly or partly was committed in Denmark and the act is not an offence according to Danish law. The same - but only as an optional rule - is true if the act was not committed in the issuing Member State, and a similar act committed outside Denmark would not be included under Danish jurisdiction (c.f. Art. 10 f(2)). In other words, an arrest warrant can be refused if the issuing Member State exercises so-called extraterritorial jurisdiction in cases where there is no similar Danish extraterritorial jurisdiction. The latter rule is in accordance with the optional rule in Art. 4(7) letter b.

It should be noted that the very fact that the alleged act is in accordance with the Framework Decision's Art. 8 letters d and e (and Art. 18 a(1) in the Danish Act on Extradition of Offenders) must be expressed in the arrest warrant so that it will be possible for the Danish executional judicial authorities to check whether the alleged act corresponds to one of the listed crimes - not in accordance with Danish law, but in accordance with a more abstract definition of the relevant crime. There does not appear to have been any case in Denmark where the issuing Member State's described act has not been considered to be one of the 32 crimes on the positive list.

With regard to cases which are not covered by the positive list, execution of an arrest warrant for the purpose of conducting a criminal prosecution requires that the act for which the European arrest warrant has been issued constitutes an offence under Danish law (Art. 10 a(2) in the Danish Act on Extradition of Offenders). In these cases the executing judicial authority in Denmark investigates rather thoroughly the condition of double criminality. Thus, the issuing Member State's description in the arrest warrant of the facts of the case are in these cases compared

\footnotetext{
${ }^{71} \mathrm{Cf}$. Forslag til lov om cendring af lov om udlevering af lovovertrcedere og lov om udlevering af lovovertrcedere til Finland, Island, Norge og Sverige (L 433/2003), Sect. 4.1.2.1 (Amendment of the Act on Extradition of Offenders and the Act on the Extradition of Offenders to Finland, Iceland, Norway and Sweden (Implementation of the EU Framework Decision on the European Arrest Warrant, etc.) Translation by the author.
} 
to the relevant criminal offences in Danish law to make sure that the elements of the crime (actus reus) in the issuing Member State correspond with the elements of the crime in Danish law. ${ }^{72}$ On the other hand, it is not required that the legal classification of the act be the same in both Member States. It is sufficient that the charge concerns an act which would have been considered an offence if committed in Denmark. This state of the law was explicitly stated in the preparatory work to the Danish Act on Extradition of Offenders, ${ }^{73}$ and the Danish case law does not seem to be inconsistent with this. ${ }^{74}$

It is to be noticed that the rules on extradition must be considered as procedural rules with the implication that they in general are held to apply to all proceedings pending at the time when they enter into force and with retroactive effect (contrary to substantive criminal rules which are to be interpreted as not applying to situations existing before their entry into force). This appears from the Danish Act on Extradition of Offenders, the Danish case law (U 2004.2229 H) and the CJEU judgment. ${ }^{75}$ This state of the law has not been criticised in Danish legal doctrine, since extradition cannot be put on the same footing as criminal liability with retroactive effect. This results from the fact that extradition either relates to extradition for the purpose of conducting a criminal prosecution (where possible criminal liability will be determined) or relates to extradition for the purpose of execution of a prison sentence handed down in a judgment (where criminal liability has already been determined).

The overall assessment in the field of nullum crimen, nulla poena sine lege is that the legal protection inherent in the principle is still fully granted the same level of protection as prior to the entry into force of the Framework Decision on the European Arrest Warrant - even though the full protection will not be implemented before the main hearing in the issuing Member State.

\subsubsection{Fair Trial and In Absentia Judgments}

2.3.3.1 With regard to in absentia judgments, no constitutional issues have been raised in Denmark due to the fact that the Danish Constitution does not regulate the defendant's right to participate in oral proceedings or the right of the person in question to mount his or her own defence. These rights are regulated in the Danish Administration of Justice Act. Here the main rule is that the defendant has a right

\footnotetext{
${ }^{72}$ See i.e. the Western High Court's decision of 13 September 2005 (U 2006.7 V).

${ }^{73}$ C.f. Forslag til lov om cendring af lov om udlevering af lovovertrcedere og lov om udlevering af lovovertrcedere til Finland, Island, Norge og Sverige (L 433/2003), Sect. 4.1.2.1. (Amendment of the Act on Extradition of Offenders and the Act on the Extradition of Offenders to Finland, Iceland, Norway and Sweden (Implementation of the EU Framework Decision on the European Arrest Warrant, etc.)).

${ }^{74}$ See e.g. the Eastern High Court's decision of 25 April 2013 (U 2013.2240 Ø).

${ }^{75}$ See C-399/11 Melloni [2013] ECLI:EU:C:2013:10, paras. 31-32.
} 
(and a duty) to be present at all stages of the trial and he or she has a right to have access to the case file, either personally or through a defence lawyer. These rights can be limited in special circumstances. If the person is present at the proceedings, the defendant always has the right to the last word. The Danish Administration of Justice Act also contains rules on the conditions for lodging an appeal and the conditions for a re-trial in the event of a judgment in absentia. The main rule is that the convicted person has full access to lodge an appeal or to petition for a re-trial if he or she was not aware of the scheduled trial in due time or there are other excusable circumstances.

When the Danish Act on Extradition of Offenders was amended in order to implement Council Framework Decision 2009/299/JHA of 26 February 2009 amending Framework Decisions 2002/584/JHA, 2005/214/JHA, 2006/783/JHA, 2008/909/JHA and 2008/947/JHA, thereby enhancing the procedural rights of persons and fostering the application of the principle of mutual recognition to decisions rendered in the absence of the person concerned at the trial, ${ }^{76}$ in the Danish preparatory works of the amendment bill the issue of whether the European Arrest Warrant (EAW) rules on in absentia judgments were in breach of any fundamental rights was not called into question. Regarding the compatibility of the EAW rules on in absentia judgments with Art. 6 ECHR, the preparatory works only state:

Under Art. 6 of the European Convention on Human Rights and the European Court of Human Rights case law defendants in criminal cases generally have the right to be present at trial.

In the conduct of a criminal trial without the presence of the accused, in order to be compatible with Art. 6 of the Convention, the accused must be summoned to the hearings in the manner prescribed in national law, unless the accused can be assumed to have waived his right to be present, and the conduct of the criminal proceedings has sufficient procedural safeguards. According to the Court's case law it is a condition that the authorities have made reasonable efforts to make the accused aware that there are initiated criminal proceedings against the person concerned. ${ }^{77}$

In Danish jurisprudence the rules on in absentia judgments have not given rise to any fundamental considerations. The same is true for the legal theory.

The overall assessment in the field of in absentia judgments is that fundamental rights are not compromised, and that the national courts do not have to revisit the standard of protection in the case of in absentia judgments in the context of the EAW Framework Decision. ${ }^{78}$

\footnotetext{
76 [2009] OJ L 81/24.

${ }^{77}$ C.f. Forslag til lov om cendring af lov om fuldbyrdelse af visse strafferetlige afgørelser $i$ Den Europaiske Union og lov om udlevering af lovovertrcedere (L 271/2011), Sect. 3.1.3 (Amendment of the Act on Execution of Decisions in Criminal Matters in the European Union) Translation by the author.

${ }^{78}$ Council Framework Decision of 13 June 2002 on the European arrest warrant and the surrender procedures between Member States (2002/584/JHA), [2002] OJ L 190/1.
} 


\subsubsection{The Right to a Fair Trial - Practical Challenges Regarding a Trial Abroad}

2.3.4.1-2.3.4.2 According to Art. 18 b(3), taken in conjunction with Art. 14 of the Danish Act on Extradition of Offenders, the person whose extradition is sought has a right to a defence lawyer. This right exists from the very moment the Danish executing judicial authority (the Ministry of Justice) receives a European arrest warrant unless the executing judicial authority already on the basis of the arrest warrant refuses to extradite the person in question. The cost and expenses relating to the assignment of the defence lawyer and other expenses are to be defrayed by the state unless the court under extraordinary circumstances decides otherwise.

If the executing judicial authority, after an examination of the case, decides to extradite the person concerned, the police (who have conducted the examination on behalf of the executing judicial authority) are, at the person's request, obliged to bring the case to court. The court is then called upon to rule on the legality of the decision. The case is then tried by the municipal court, and the person concerned can lodge an appeal to the high court if the municipal court upholds the decision to extradite. In exceptional circumstances the case can be referred to the Supreme Court. The actual extradition cannot be executed until the final ruling has been passed.

Because of the above-mentioned rules and the practical circumstances in the event of an extradition in Denmark, there does not seem to be any need to recommend the introduction of a publicly funded state or non-governmental body to provide assistance to residents who are involved in trials abroad. This is true even though an assigned defence lawyer is released from his or her duties when the final decision on extradition has been passed, since the Framework Decision is built on the principle of mutual trust and thereby on confidence and trust among Member States regarding the same level of protection and the same respect for the rule of law, including the obligation to respect fundamental rights and fundamental legal principles - such as the right to a defence lawyer.

\subsubsection{The Right to Effective Judicial Protection: The Principle of Mutual Recognition in EU Criminal Law and Abolition of the Exequatur in Civil and Commercial Matters}

2.3.5.1 The overall assessment is that the legal protection inherent in the principle of effective judicial protection and the rule of law are still fully granted the same level of protection as prior to the entry into force of the Framework Decision on the European Arrest Warrant - even though the full protection takes place in two locations, namely both in the issuing Member State and in the executing Member State. 
2.3.5.2 There has not been a true debate about the suitability of transposing mutual recognition from internal market matters to criminal law and civil and commercial disputes. This is probably because the instruments built on the principle of mutual recognition were adopted on an intergovernmental basis and not on a supranational basis. ${ }^{79}$ Because EU citizens move freely across the borders inside the EU and because criminals also exercise their right to free movement, the transposing of mutual recognition seems to be a rational consequence of cooperation in the field of the internal market.

2.3.5.3 No concerns have been expressed in Denmark about a change in the role of the courts as an implication of the Framework Decision on the European Arrest Warrant. This may be due to the fact that the role of Danish courts has not changed in principle in the proper sense of the word, and to the fact that a decision on extradition, on the requested person's demand, can be subjected to judicial review of the legality of the decision to extradite as outlined above.

2.3.5.4 On the other hand, everything is not just fine and there is significant room for improvement.

As mentioned in the questionnaire, there has been a call for the introduction of a proportionality test prior to an extradition request and prior to extradition based on an arrest warrant to avoid the extradition of citizens for a wide range of so-called 'trivial offences'. This has also been called for in Denmark. ${ }^{80}$ Regardless of mutual recognition and trust, extradition to another country in preparation for a trial or for the purpose of executing a prison sentence handed down in a judgment is nevertheless an extremely serious matter. Such a severe measure calls for a high degree of justification. This requirement is not satisfied if the crime committed only amounts to what is classified as a minor criminal offence.

Moreover, even the European Commission has called for a proportionality test including in jurisdictions where prosecution is mandatory. The Commission has in this regard stated that the application of the European arrest warrant has been undermined by the systematic issue of arrest warrants for the surrender of persons sought in respect of often petty offences even though there is a general agreement among the Member States that a proportionality check is necessary to prevent European arrest warrants from being issued for offences which - although they formally fall within the scope of the Framework Decision - are not serious enough to justify the measures and cooperation which the execution of an European arrest warrant requires. Against this background the Commission recommends that the issuing Member State, ${ }^{81}$ before issuing a European arrest warrant, take not only the seriousness of the offence but also the length of the expected sentence and the principle of least burdensome means, etc., into consideration. The Commission has

\footnotetext{
${ }^{79}$ Criminal law cooperation as such has been vivaciously debated in Denmark and has caused, among other things, the Danish opt-out. See further Baumbach 2013, pp. 300 et seq.

${ }^{80}$ See e.g. Elholm 2011, pp. 28 et seq.

${ }^{81}$ Including those jurisdictions where prosecution is mandatory.
} 
stated outright that there is a disproportionate effect on the liberty and freedom of requested persons when European arrest warrants are issued concerning cases for which (pre-trial) detention would otherwise be deemed inappropriate. ${ }^{82}$

The European Commission has urged Member States to take positive steps to ensure that practitioners use the handbook on the EAW adopted by the Council of the European Union as amended following the recommendations in the final report on the fourth round of evaluation. The handbook includes a separate chapter on the principle of proportionality. ${ }^{83}$ It is underlined in the handbook that notwithstanding the fact that an issuing Member State is not obliged to conduct a proportionality check and the legislation of the Member States plays a key role in that respect, the competent authorities should, before deciding to issue a warrant, consider proportionality by assessing the aspects stressed above.

In this author's view a proportionality test ought to be mandatory and legally binding and ought to thereby also take precedence over any mandatory prosecution rule in the issuing Member State. In this connection it is important to bear in mind that the instrument in principle is designed to further the prosecution of more serious or more damaging crimes which may substantially justify its use or for the purposes of enforcing convictions. The European arrest warrant was adopted in the wake of the terror attacks $(9 / 11)$ in the USA and must be interpreted and applied in that light. In other words, the Framework Decision on the European arrest warrant is a tool in the fight against genuine crime, not just a tool for expediency.

Another relevant issue in the context of the Framework Decision on the European arrest warrant is - in this author's view - the sometimes missing link between the offence and the country to which the individual is extradited. There seems to be no reason not to require such a link. The instrument should therefore be limited to cases where the offence is committed in, or in other legally relevant ways related to, the issuing Member State. This seems to be of particular importance in relation to cases covered by some of the offences listed in the positive list, for instance racism and xenophobia, which are defined differently in the individual Member States. Such a limitation would also be most consistent with the freedom of expression as defined in Art. 11 of the EU Charter of Fundamental Rights and in Art. 10 ECHR.

A recommendation to reinstate a judicial review in the context of extradition to ensure that the offence is sufficiently serious and that there is a sufficient link between the offence and the issuing Member State to which the individual is extradited would seem to be a suitable instrument towards a more balanced regulation of the field.

\footnotetext{
${ }^{82}$ See further Report from the Commission to the European Parliament and the Council on the implementation since 2007 of the Council Framework Decision of 13 June 2002 on the European arrest warrant and the surrender procedures between Member States, $\operatorname{COM}(2011) 175$ final, pp. 7 et seq.

${ }^{83}$ Chapter 3, cf. European handbook on how to issue a European arrest warrant, Council 17195/ 10 , COPEN 275, pp. 14 et seq.
} 


\subsubsection{Constitutional Rights Regarding Other Aspects of EU Criminal Law}

Due to Denmark's justice opt-out, Denmark does not have further constitutional issues in relation to European Union criminal law.

\subsection{The EU Data Retention Directive}

2.4.1 The implementation of the Data Retention Directive ${ }^{84}$ did not raise constitutional issues. $^{85}$

Article 72 of the Constitution states:

The home is inviolable. House searches, the seizure and examination of letters and other documents and breach of the confidentiality of the post, telegraph and telephone can only take place when authorised by a Court order where there is no authority in an Act for a specific exemption.

Article 72 provides procedural protection but not substantive protection of the inviolability of the home. Interference by the authorities with an individual's communication is considered legitimate in so far as it is founded on a legal basis. This follows from the unwritten principle of legality. A court order is not necessary where an Act of Parliament dispenses this requirement. The requirement of a court order set out in Art. 72 is dispensed with in 200 cases in Danish legislation. ${ }^{86}$ The principle of proportionality is only interpreted together with constitutional provisions which provide substantial rights protection and hence not together with Art. 72 which only provides procedural protection. ${ }^{87}$

The legal basis for data retention is Art. 786 of the Administration of Justice Act. Data retention is therefore in accordance with the formal requirements of the Danish Constitution.

There have been no cases before the Supreme Court on the Data Retention Directive. Following the annulment of the EU Data Retention Directive by the CJEU, the Danish Ministry of Justice considered the impact of the judgment on the Danish legislation on data retention. In a memorandum dated 2 June $2014^{88}$ the

\footnotetext{
${ }^{84}$ Directive 2006/24/EC of the European Parliament and of the Council of 15 March 2006 on the retention of data generated or processed in connection with the provision of publicly available electronic communications services or of public communications networks and amending Directive 2002/58/EC, [2006] OJ L 105/54.

${ }^{85}$ However, the Directive has given rise to debate regarding its compliance with Art. 8 of the ECHR. See Rytter 2010, p. 195.

${ }^{86}$ See Rytter 2013, p. 227.

${ }^{87}$ Ibid., p. 114.

${ }^{88}$ See Notat om betydningen af EU-Domstolens dom af 8. april $2014 i$ de forenede sager C-293/12 og C-594/12 (om logningsdirektivet) for de danske logningsregler, 2 June 2014. (Memo on the importance
} 
Ministry concluded that the Danish legislation does not violate Arts. 7 and 8 of the Charter. ${ }^{89}$ According to the Ministry, the Danish legislation contains clear and precise rules for when the authorities can be given access to logged information and for which period such information must be stored. However, it is questionable whether the specific provisions on logging sessions can be viewed as suitable for achieving their purpose. Based on this concern, the Minister of Justice decided to annul these specific provisions. ${ }^{90}$

\subsection{Unpublished or Secret Legislation}

2.5.1 According to Art. 22, Acts must be made public. This is done by publishing them in a special journal Lovtidende (journal of laws) which is now also available on the Internet. The purpose of Art. 22 is to provide citizens with protection against secret legislation. ${ }^{91}$ Normally, Acts do not take effect for citizens before they are published. If possible, an Act must be interpreted in such a way that even though the Act expresses the state of the law from the time it comes into force, it is not executed for instance through imposing arrest or the use of force on individuals until it is made public. However, there is no general principle prohibiting the retroactivity of Acts in Danish constitutional law. This means that if retroactivity is clearly intended by the legislator, this is not unconstitutional and must be upheld by the courts even though it is disturbing. This rarely happens in reality and the case law in this field is rather limited. The leading judgment is from 1956 (U 1958.955Ø). ${ }^{92}$ It should also be mentioned that the debate and the U $1958.955 \varnothing$ case concerned the question whether an Act can be executed in the night/early morning if the Lovtidende is not delivered by post until some hours later. Now that the Lovtidende is on the Internet, this problem seems to be at least to some extent resolved.

\subsection{Rights and General Principles of Law in the Context of Market Regulation: Property Rights, Legal Certainty, Non-retroactivity and Proportionality}

2.6.1 These issues have not been addressed in Danish case law.

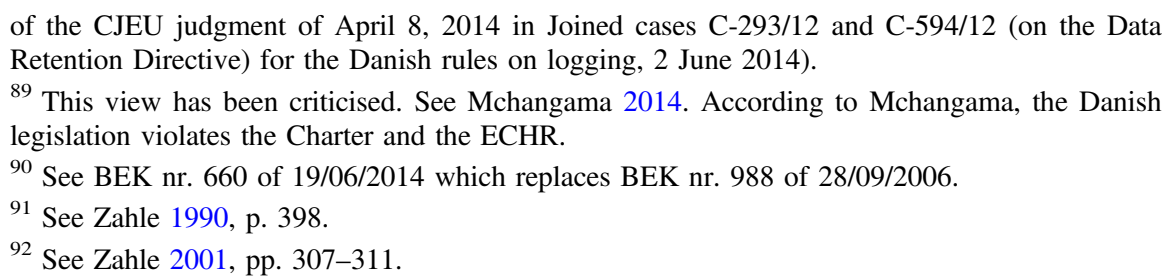




\subsection{The ESM Treaty, Austerity Programmes and the Democratic, Rule-of-Law-Based State}

2.7.1 Denmark is not a member of the eurozone. However, Denmark has ratified the Treaty on Stability, Co-ordination and Governance (TSCG) and takes part in the Treaty as described in Art. 14. Since Denmark is not part of the eurozone and has not suffered from the financial crisis as severely as many other countries, there has not been much debate on the TSCG. The Danish debate mainly focused on whether Denmark could ratify the Treaty through the normal procedure in Art. 19 which only requires consent from a majority of the Members of Parliament or whether the Art. 20 procedure was necessary. If ratification were to lead to a transfer of sovereignty, five-sixths of the Members of Parliament would have to be in favour of ratifying the Treaty or a referendum would have to be held under Art. 20. The Danish Ministry of Justice examined the TSCG with a special view to part III and IV and found that ratification did not require the Art. 20 procedure, since no sovereignty was transferred. Some of the Articles in the Treaty, such as Art. 7, only impact Member States whose currency is the euro and therefore do not concern Denmark. Furthermore, the Ministry of Justice does not consider that the Treaty raises other problems in relation to the Danish Constitution. ${ }^{93}$

\subsection{Judicial Review of EU Measures: Access to Justice and the Standard of Review}

2.8.1 (a)-(c) An interesting feature of the Danish system of references of preliminary questions to the CJEU is that when a party asks for a preliminary reference, the courts will seek advice from the Government's judicial committee through the state attorney before requesting a preliminary ruling. This committee, which is also the adviser to the Government on the implementation of EU law, rarely recommends a request for a preliminary ruling. ${ }^{94}$ However, the Committee is primarily, though not exclusively, involved in cases in which the Danish state is involved. In civil cases with two private parties, the Committee is not always involved, but when it has been, it has more often recommended a reference. ${ }^{95}$ In a survey, $69 \%$ of the Danish judges consulted answered that the most important reason for not referring a

\footnotetext{
93 See Notat om visse forfatningsretlige spørgsmål $i$ forbindelse med Danmarks ratifikation af traktaten om stabilitet, samordning og styring $i$ Den Økonomiske og Monetcere Union (den såkaldte finanspagt). (Memo on certain constitutional issues in connection with Denmark's ratification of the Treaty on Stability, Coordination and Governance in the Economic and Monetary Union (the so-called European Fiscal Compact)), 22 February 2013.

94 See Pagh 2008, pp. 475-511.

95 See Rytter and Wind 2011, p. 470, n. 88.
} 
case to the CJEU was the advice given to them by the Danish Government's attorney. $^{96}$

It has not been possible to find data on the number of cases in which the applicants have requested a preliminary ruling with regard to the validity of an EU measure since 2001 .

Since 2006, Denmark has requested a preliminary ruling in 57 cases, of which 11 cases are still pending and 46 cases are closed. None of these cases has regarded the validity of an EU measure.

2.8.2 Denmark does not have a Constitutional Court and has no prima facie review in the courts. Danish courts can only perform ultra vires review and only if the plaintiff has a sufficient legal interest in having the case tried before the courts. For further information on the system of review in Denmark, see Sect. 2.8.3.

To my knowledge the standard of review has not been researched in the Danish context. I do not have any statistical data on the success rate in Danish courts which could be compared to the data in the EU Courts provided by the questionnaire. However, traditionally, Danish courts do not find violations based entirely on legal principles. Normally a violation will build on a legal basis in written legislation or the Constitution (perhaps supported by a legal principle), which has been violated. Danish courts are rather positivistic in their approach. This also means that they normally do not engage in very dynamic interpretations of, for instance, rights. ${ }^{97}$ At the FIDE congress 2014, the President of the Danish Supreme Court stated:

Danish courts serve the law, we are not put on earth to attain more power, and we are not eagerly seeking opportunities to overrule legislation by stretching principles for their own sake. Excessive innovation and adventurism by judges is not something you will find in Denmark. Danish judges view that creative judicial activism may endanger the rule of law. ${ }^{98}$

Compared to the Danish legal tradition, both the CJEU and the ECtHR must be considered very dynamic in their interpretations.

Obviously, the recent development in the Danish Supreme Court which follows from $\mathrm{U} 2014.914 \mathrm{H}$, the recent request for a preliminary ruling ${ }^{99}$ and Børge Dahl's statements at the FIDE conference 2014 (see e.g. the long quote in Sect. 2.1.3) are interesting since they reflect (1) the importance of general legal principles and (2) a critique of the CJEU for not upholding the principles of the rule of law, legal foreseeability and legal certainty in its judgments. One way of interpreting this is that the standard of judicial review in the national courts is not sufficient because of the dynamic interpretations by the CJEU.

\footnotetext{
96 See Rytter and Wind 2011, p. 470.

${ }^{97}$ On Danish judicial self-restraint and the new European context with dynamic interpretations from the CJEU and the ECtHR, see Rytter and Wind 2011, p. 470.

98 See Dahl 2014, p. 27.

99 See Supreme Court decision of 22 September 2014 (Sag 15/2014, 1. Afdeling) and C-441/14.
} 
2.8.3 Danish courts in general have quite a deferential approach to review of the constitutionality/legality of legislation, regulatory acts of the executive branch and administrative action. The Danish concept of democracy builds on a strong Parliament/legislator and reluctant courts, which are very careful to not act in a 'political' manner. Politicians are viewed as having democratic legitimacy through elections as compared to judges. As mentioned, Danish courts have a positivistic approach and do not normally engage in dynamic interpretations.

Danish courts have the competence to review the constitutionality of legislation. However, this important competence cannot be found in the text of the Constitution, even though this competence was legally and politically accepted in 1953, the last time the Constitution was amended. Danish courts will normally only rule that an Act is unconstitutional if a clear violation of the Constitution can be established. The Danish Supreme Court has only once found that an Act violated the Constitution. This was in the so-called Tvind-case, U 1999.841H. The Supreme Court stated that the legislator had violated the separation of powers between the legislator and the courts in Art. 3 of the Danish Constitution.

2.8.4 Denmark has no a priori review by the courts. The Ministry of Justice considers whether new legislation is coherent with the Constitution, existing legislation, EU law and international treaties which Denmark has signed, including the ECHR.

In the Danish Maastricht judgment, U $1980.800 \mathrm{H}$, the Supreme Court stated that the Constitution, including human rights protection, has supremacy over EU Law. The competence to legislate in a way that violates the human rights protection in the Constitution cannot be transferred according to Art. 20, since Danish authorities do not have such competence. Furthermore, according to the Supreme Court, Danish courts have the right and the duty to step in if it can be established with sufficient certainty that the EU by an act or a judgment has gone beyond the competences which Denmark has transferred to the EU according to Art. 20 of the Danish Constitution. This was confirmed in the Danish Lisbon Judgment. ${ }^{100}$

In the Lisbon judgment the Supreme Court found that there was no basis for concluding that Art. 20 of the Danish Constitution had been violated. However, the Court stated:

However, a case involving an act or a judicial decision adopted or delivered pursuant to the relevant Treaty provisions and having a specific and real impact on citizens etc., would provide a better basis for hearing the dispute. ${ }^{101}$

And further:

If EU acts are adopted or if the Court of Justice delivers judgments with reference to the European Convention on Human Rights, based on an interpretation of the Treaties that contravenes this constitutional assessment, it will be possible to submit this to a judicial review as stated in the Maastricht judgment (paragraph 9.6).

${ }^{100}$ Supreme Court decision of 20 February 2013, Case No. 199/2012, p. 16, U 2013.1451H. ${ }^{101}$ Ibid. 
Thus, the Supreme Court can be expected to review EU acts and judgments more actively in concrete cases in the future. However, this will require that the plaintiffs have legal standing in the form of a legal interest in having the case tried before the courts.

There is no Danish equivalent to the Solange $I I^{102}$ or Bosphorus ${ }^{103}$ judgments that would assume that the standard of protection of rights in the EU is equivalent to that provided by the ECtHR or the national standard, unless the applicant proves a significant fall of standards.

2.8.5 Not relevant in the Danish context.

2.8.6 In the Danish context, the equal treatment of individuals falling within the scope of EU law and those falling outside the scope of EU law has primarily been discussed in relation to EU citizens from other EU countries who receive social benefits in Denmark and protection against 'social tourism'. ${ }^{104}$ Furthermore, attention has been paid to cases from the CJEU on citizenship and third country nationals, for instance relating to the national competence to grant and revoke citizenship, and the competence of the Member States to exercise reverse discrimination. ${ }^{105}$

\subsection{Other Constitutional Rights and Principles}

2.9.1 In the winter/spring of 2015 discussions took place in the Danish Parliament regarding parliamentary control of the implementation of EU directives. Parliament was concerned since the executive implements EU directives by administrative acts in nine out of ten cases. ${ }^{106}$ According to the chairman of the European Policy Committee, this means that parliamentary control is cut off. ${ }^{107}$ The Minister of Justice on the other hand emphasised that Parliament is almost always involved in the negotiations of proposals on new EU legislation though the European Policy

\footnotetext{
10219 BVerfGE 73, 339 [1986] (Solange II).

${ }^{103}$ Bosphorus Hava Yollar Turizm ve Ticaret Anonim Sirketi v. Ireland [GC], no. 45036/98, ECHR 2005-VI.

${ }^{104}$ See for instance Jacqueson 2010, pp. 152-166, on the right of EU citizens to receive social welfare benefits. From the press see for instance: Pedersen, K. (2009, May 25). Arbejdsløse EU-borgere fär flere penge end danskere (Unemployed EU citizens receive more money than Danes). Information. See also Røndbjerg-Christensen, H. (2014, March 11). Dansk dagpenge-slagsmål adskiller sig fra børnecheck-sagen (Struggle over Danish unemployment benefits differs from the child allowance case). Berlingske.

${ }^{105}$ See for instance Krunke and Schulyok 2014, pp. 107-152.

${ }^{106}$ See Winther, B. (2015, April 17). Folketinget slår alarm: Vi kobles af EU-lovgivning (The Danish Parliament raises the alarm: We are disconnected from EU legislation). Berlingske. http:// www.politiko.dk/perspektiv/folketinget-slaar-alarm-vi-kobles-af-eu-lovgivning. ${ }^{107}$ Ibid.
} 
Committee. The Government writes memos to the Parliament on all proposals for new directives and proposals for important regulations, and presents these to the European Policy Committee. ${ }^{108}$ On 7 May 2015 the Danish Parliament adopted a parliamentary resolution stating that in the future Parliament shall always be informed if a bill or an administrative act goes further in implementing a directive than requested by the EU. Furthermore, the Government is in general requested to inform Parliament when implementing EU directives and regulations. ${ }^{109}$

\subsection{Common Constitutional Traditions}

2.10.1 It seems that values such as democracy, separation of powers, independent courts and basic human rights, for instance the political freedoms, right to privacy, etc., are common values. Many of these values are already part of the common values of the EU. The Danish Constitution does not expressly mention any constitutional principles. Furthermore, the human rights charter in the Constitution is not very detailed and stems from 1953. At that time it was not possible to foresee phenomena such as massive data retention. Hence, rights of a more modern character are not touched upon. Since the courts are not especially dynamic, such rights do not follow from case law either.

The courts are normally also rather reluctant to refer to constitutional or legal principles. However, as pointed out, in recent developments the Supreme Court has emphasised the importance of general legal principles such as the rule of law, legal certainty and foreseeability as a reaction to dynamic case law from the CJEU.

The question of national constitutional identity is related to question 2.10.1. This concept and its content will probably develop in the future. At present, Danish courts have not contributed much to defining the Danish constitutional identity as compared to the German Constitutional Court's role in defining the German constitutional identity. ${ }^{110}$ Perhaps a few very general points can be found in the Danish Maastricht and Lisbon judgments, such as the constitutional precondition of a democratic form of government and the requirement that Denmark must remain an independent state; however, constitutional identity has not expressly been mentioned. ${ }^{111}$

\footnotetext{
${ }^{108}$ See the answer of the Minister of Justice to question No. 7 of 21 April 2015 from the European Policy Committee, annex to B52.

${ }^{109}$ See Resolution by Parliament on information of the Parliament regarding implementation of EU directives, regulations and administrative regulations of 7 May 2015, and Report on information of the Parliament regarding implementation of EU directives, regulations and administrative regulations by the European Policy Committee of 24 April 2015.

${ }^{110}$ As regards Danish national constitutional identity, see Krunke 2014a.

${ }^{111}$ See ibid. and Krunke 2014b, pp. 542-570.
} 
2.10.2 Since the question is related to identifying constitutional national identity, this is also a question of how to identify national constitutional identity in the Member States. Obviously, the Constitutions and case law from the national constitutional court and/or supreme court play a role in this, and attaching relevant information on national constitutional traditions to references for a preliminary ruling, as suggested, could be a good instrument. Another place to look might be international treaties, for instance on human rights, which all EU Member States have entered into. A third suggestion could be to study how the national parliaments have used the Early Warning System, since this might reflect some common values and would also include parliaments and not just courts in defining national values and constitutional identity. Fourthly, one might search for national constitutional identity in the Member States' exceptions from the EU treaties. ${ }^{112}$ National exceptions might indicate areas where no common European ground has been found, thus indirectly contributing to defining the values that are common.

\subsection{Article 53 of the Charter and the Issue of Stricter Constitutional Standards}

2.11.1 There has been no debate on these particular issues. Interestingly, Jens Elo Rytter presumes that no conflict between constitutional human rights and EU fundamental rights can arise, since the EU protection of fundamental rights, according to Art. 53, does not prevent a higher national constitutional standard. ${ }^{113}$ As pointed out, the last revision of the Danish Constitution took place in 1953. The human rights charter is of a classic character, not very extensive and some would say not of a modern standard. Hence, the ECHR plays an important role in human rights protection.

\subsection{Democratic Debate on Constitutional Rights and Values}

2.12.1 Some debate took place around the time of the adoption of the European Arrest Warrant Framework Decision. ${ }^{114}$ More public debate has followed since it is now possible to see the impact of the European Arrest Warrant Framework

\footnotetext{
112 See Krunke 2014b, pp. 542-570.

113 See Rytter 2013, p. 48.

114 See e.g. Wilhjelm, P. (2002, May 23) Den Europaiske arrestordre (The European arrest warrant). Politiken. http://politiken.dk/debat/kroniken/ECE33513/den-europaeiske-arrestordre.
} 
Decision. The critique is inter alia based on the principle of legal certainty and existing legal principles relating to the extradition of criminals. ${ }^{115}$

As regards the EU Data Retention Directive, some debate took place at the time of the national implementation and included critique related to the principle of proportionality. ${ }^{116}$ Since the judgment of the CJEU, more public debate has followed.

2.12.2 As mentioned in Sect. 2.8.2, Denmark does not have a Constitutional Court and no a priori review in the courts. Furthermore, Danish courts can only perform ultra vires review if the plaintiff has a sufficient legal interest in having the case tried before the courts.

The question of suspension has both a democratic dimension and a legal dimension. As regards the democratic dimension, the question is about allowing room for public debate at the national level. Public debate is of course a cornerstone of democracy and should be supported and encouraged not only by national politicians but also by the EU. Hence, sufficient time should be given for this. However, there must also obviously be a time limit for such public debate, as otherwise it would be very difficult to legislate in an international organisation consisting of 28 Member States.

It also has a legal dimension since the core of this question is the legal relationship between EU law and national law. As is well known, according to EU Law, EU law is superior to national law, including the national constitutions. However, according to many national constitutional systems, the Constitution is superior to EU law. This has been expressed by a number of national courts, including the German Constitutional Court and the Danish Supreme Court. If one follows EU law viewed from a purely legal angle, implementation cannot be delayed because a case is pending in a constitutional court, since EU law has supremacy over the national constitutions. The principle of supremacy and the principle of direct effect are important EU principles built on efficiency and equality arguments. However, under national constitutional law suspension would make more sense, since many national constitutional systems do not accept the principle of supremacy.

2.12.3 As mentioned, this question on suspending the application of an EU measure touches upon the premise of the supremacy of EU law. Obviously, viewed from the angle of many constitutional systems, this would make sense since EU law cannot violate the national constitution. One might also put forward that if, according to a number of constitutional courts, an EU measure violates national general legal principles and rights, then this would be a good reason for the EU to reconsider the

\footnotetext{
115 See e.g. Mchangama J. (2011) Den Europaiske arrestordre er en trussel med retssikkerheden (The European arrest warrant is a threat to legal certainty). CEPOS, 2 March 2011.

116 See e.g. Gjerding, S. and Andersen, P. (2012, April 28). Minister kan ikke svare på, hvad internet-logning bruges til (Minister cannot answer what internet logging is used for). Information. http://www.information.dk/299538. This refers to critique raised in 2007.
} 
measure regardless of the principle of supremacy, since EU cooperation builds on democratic values, human rights, etc.

However, not all Member States have constitutional courts and therefore only some Member States would be able to reject an EU measure based on judgments from the constitutional court. This might create an imbalance between the Member States.

A measure such as the one proposed could in reality create a veto-right, and only for some Member States. This should be taken into consideration even though the idea of promoting general legal principles and human rights is attractive.

\subsection{Experts' Analysis on the Protection of Constitutional Rights in EU Law}

2.13.1 As pointed out, the Danish Supreme Court is worried about the standard of protection of general legal principles such as the rule of law, legal certainty, foreseeability and legal expectations. The Former President of the Danish Supreme Court has stated that this concern is shared by judges in other Member States. ${ }^{117}$ Obviously, such a concern within the national courts in the Member States should be taken seriously both at the national level and at the EU level. These principles are also EU principles, and although they might have a slightly different content in EU law, there seems to be no doubt that the principles express legal values that are also shared by the EU legal system.

2.13.2-2.13.4 An extensive overview of all EU measures and the CJEU's interpretation of them would be required to answer this question. The Danish Supreme Court has expressed a growing concern and it is important to note that the Supreme Court only receives cases in which a plaintiff has legal standing in the form of a legal interest in the case. Furthermore, not all cases reach the Supreme Court due to procedural rules or because the cases are not appealed. Thus, the judges only see 'random samples', which might be just the tip of the iceberg. The Danish Supreme Court has heard a number of cases where a national judgment which followed the CJEU's interpretation of an EU measure or an unwritten principle developed by the CJEU would require the Supreme Court to rule contra legem as regards national legislation. This would be in contradiction with fundamental legal principles such as the rule of law, legal certainty and legal foreseeability. This obviously shows that the CJEU's dynamic interpretation style in certain cases creates a state of the law which was not foreseeable for the Member States, private parties, national judges, etc. According to EU law, the duty to interpret national legislation in conformity with EU law does not include a duty to interpret contra legem. If the CJEU were to uphold this in the mentioned case, C-441/14, referred to the CJEU for a preliminary

117 See quotation above in Sect. 2.1.3, n. 50 . 
ruling from the Danish Supreme Court, one might put forward that the private party in the concrete case would not suffer any loss. However, the practice of the Danish Supreme Court still reveals that the interpretations of the CJEU are not always predictable and that this unpredictability in certain cases can be so extensive that a contra legem situation is reached. Case C- $441 / 14^{118}$ relates to the unwritten principle of the prohibition of age discrimination as recognised by the CJEU.

The Danish cases regard the CJEU's interpretations of EU measures which can appear years after the adoption of the measures by the political institutions. Furthermore, the Danish cases regard the CJEU's development of unwritten principles with the same legal status as the EU treaties. Several possible solutions could be mentioned such as a greater awareness within the CJEU of the importance of general legal principles and a strengthened legal value attached to travaux préparatoires when interpreting EU measures. Allowing for dissenting opinions would support a nuanced debate within the CJEU and strengthen legal arguments, since it would create more focus on 'differences'. It would also support public debate. A strengthened dialogue between the CJEU and the national courts and a more proactive role by the courts would seem to advance a solution, since this would highlight problems. However, solutions might also be sought by the political institutions. The EU legislator can seek to be clearer when formulating new EU measures. The EU's political institutions could engage in a debate following concrete CJEU judgments which give EU measures an interpretation far from that which was originally intended. National governments and parliaments can be better in expressing concern as regards legal principles and human rights in the legislative process. Creating a new independent judicial body which could ex ante or ex post review new EU measures in relation to constitutional principles and rights could be an effective solution. Importantly, if all Member States were represented in a judicial body, a good balance between constitutional traditions would be reached. The only concern is that such a judicial body might perhaps become a 'political' player with the power to 'veto' EU measures.

As regards the CJEU's responsiveness to national concerns, it will be very interesting to see how the CJEU responses to the Danish preliminary ruling request noted above, which refers to a number of general legal principles.

As regards the Danish context, it seems that the fact that important legal principles are not directly emphasised in the text of the Constitution and that the human rights catalogue is rather old might be a problem in relation to a strengthened focus on the constitutional identity, principles and rights of the Member States. This is to some extent strengthened by the fact that Denmark does not have a constitutional court. Furthermore, the national courts' tendency to apply general principles without referring directly to them or indicating whether they are at constitutional level deserves mention. One might state that if Denmark wants to be heard at the EU level as regards our constitutional values, principles and rights, we need to be clearer on what they are and we need to communicate them in a clearer way to the

${ }^{118}$ Case C-441/14 DI [2016] ECLI:EU:C:2016:278. 
EU. The Supreme Court has just done so in its preliminary ruling request, which is a good starting point. Other Member States are much better at formulating and communicating their constitutional values and identity to the EU and the other Member States. If Denmark wants to be part of a constitutional dialogue with the CJEU, the other EU institutions and the other Member States, we need to focus much more on our own constitutional values and identity. Whether this is sufficiently possible within the context of the present Constitution from 1953 is questionable. A public and political debate focusing on constitutional principles, values, etc., and a new Constitution based on such debate and expressing the Danish constitutional identity in a clearer way would probably strengthen the Danish 'voice' in the multi-level debate, as would the establishment of a Danish Constitutional Court.

\section{Constitutional Issue in Global Governance}

\subsection{Constitutional Rules on International Organisations and the Ratification of Treaties}

3.1.1 As mentioned in Sect. 1.3, Arts. 19 and 20 of the Danish Constitution regulate the transfer of powers to international organisations and the ratification of treaties. Articles 20 and 19, subsection 1 are quoted in Sect. 1.3.1. Article 19, subsections 2 and 3 read as follows: ${ }^{119}$

\section{Art. 19}

Subsection 2: Except for purposes of defence against an armed attack upon the Realm or Danish forces the King shall not use military force against any foreign state without the consent of the Folketing. Any measure which the King may take in pursuance of this provision shall forthwith be submitted to the Folketing. If the Folketing is not in session it shall be convened immediately.

Subsection 3: The Folketing shall appoint from among its members a Foreign Affairs Committee, which the government shall consult before making any decision of major importance to foreign policy. Rules applying to the Foreign Affairs Committee shall be laid down by statute.

Article 20 on transfer of sovereignty refers to the following very broad objective sought by an international organisation: 'international authorities set up by mutual agreement with other states for the promotion of international rules of law and cooperation'.

No specific international organisations are mentioned in the Constitution.

3.1.2-3.1.4 The Constitution has not been amended since 1953. Article 19 was introduced already in the first Constitution of 1849 although with a slightly different

${ }^{119}$ Only the first subsection of Art. 19 is quoted in Sect. 1.3.1. 
content (then Art. 23). It was amended in 1866, 1915 and 1953. Parliamentary involvement was strengthened between 1849 and 1953. As mentioned in Part 1 of this report, Art. 20 was introduced in 1953.

In a Ph.D. thesis from 2003 it is shown how the Foreign Affairs Committee has tried to copy the procedures of the European Policy Committee including the mandate procedure. ${ }^{120}$ This has been done through reports (like the European Policy Committee) and at the meetings by counting whether a majority is against the Government's position on certain foreign policy issues. The Committee has tried to force the Government to make it clear when the Government (1) informs the committee and (2) when it seeks its advice. ${ }^{121}$

In legal commentary the traditional standpoint has been that Parliament cannot legally bind the Government by legislation and/or parliamentary decisions in the field of foreign affairs because of the foreign affairs prerogative. However, the late Professor of Constitutional Law at the University of Copenhagen, Henrik Zahle, disagreed. According to him this is possible. ${ }^{122}$

\subsection{The Position of International Law in National Law}

3.2.1-3.2.2 Article 19, quoted above, regulates the application of treaties and their position in domestic law. Denmark has a dualistic legal system. As mentioned, this can be interpreted on the basis of Art. 19 and case law. ${ }^{123}$ Considerable debate took place 15-20 years ago in the legal literature on whether Denmark had moved from dualism to so-called 'practical monism'. However, recent case law from the Supreme Court confirms that Denmark has a dualistic system. ${ }^{124}$ Even though recent case law has established that non-incorporated treaties are not directly applicable within the domestic legal order, these treaties still constitute valuable sources for interpretation, which should be in accordance with the relevant ratified treaties. $^{125}$

Three important rules modify the dualistic approach to national law and international, ratified treaties: (1) Danish legal norms should be interpreted in accordance with international obligations if possible; (2) when applying national legal norms, they should be applied with the assumption that the legislator has not intended to breach international treaty obligations and (3) administrative authorities

\footnotetext{
120 See Krunke 2003. See also Krunke 2007, pp. 335-348.

121 See Report from the Foreign Policy Committee, 13 March 2000.

122 See Zahle 2006, pp. 388-391. See also Krunke 2003.

123 See for instance Rytter 2010, p. 189, and U 2006.700H, U 2010.1035 and U 2010.1547H.

124 See U 2006.700H, U 2010.1035 and U 2010.1547H.

125 See Zahle 2007, pp. 362-364. Zahle further states that if an international treaty is in direct conflict with a national legal norm and the conflict cannot be solved by applying the above mentioned rules and the legislator intended the breach with an international obligation, then the national norm must be respected by the national authorities. See ibid., p. 374.
} 
shall conduct their cases in a manner such that the breach of international treaty obligations is avoided. While Danish courts will go far to try to interpret Danish law in coherence with international obligations, there are limits to this and, as mentioned, the Danish courts have in recent years made it clear that the Danish legal system is dualistic. If international obligations are in clear conflict with Danish legislation or the Constitution (and this was not intended by the legislator), national law will be given precedence.

In an interesting case, $\mathrm{U} 2013.3328 \mathrm{H}$, a person complained about the treatment by the authorities of his citizenship application. In Denmark citizenship is accorded by a bill adopted by the legislator listing the names of the persons concerned. The Supreme Court stated that it could not review whether the plaintiff should have been included in the bill on citizenship or whether he should have been granted Danish citizenship. This is due to the prerogative of the Government to propose bills under Art. 21, and the competence of Members of Parliament to propose bills. However, the Supreme Court could review whether Denmark had violated an international obligation in this field and whether the plaintiff was entitled to compensation on this basis.

\subsection{Democratic Control}

3.3.1-3.3.2 Democratic control over foreign policy is discussed in Sects. 3.1.23.1.4.

It follows from Art. 19 that Parliament must consent to international obligations which increase or reduce Danish territory, the fulfilment of which requires the concurrence of Parliament or which are otherwise of major importance. Consent must also be given if the Government wants to denounce any international treaty entered into with the consent of the Folketing, the Danish Parliament. The Foreign Affairs Committee must be consulted before making any decision of major importance for foreign policy. Since the debates in this committee are normally confidential, the committee is a good forum for the involvement of Parliament in foreign affairs. Parliament also has normal standing committees on Foreign Policy and Defence Policy. As regards the EU Common Foreign and Security Policy, both the Foreign Affairs Committee and the European Policy Committee are involved. The above-mentioned committees also follow international cooperation after ratification.

Because of the changed landscape with more globalisation and international cooperation, power has been transferred from the legislator to the Government. Areas which were formerly entirely regulated by national legislation are now debated in international fora by representatives from the national governments. In this light it seems necessary to rethink the foreign affairs prerogative and to compensate the national parliaments for lost competence in the national constitutions.

According to Art. 42, part 6, bills introduced for the purpose of discharging existing treaty obligations cannot be decided by a referendum. If a majority of 
Parliament so decides, an Act passed under Art. 19 can be submitted to a referendum. However, Parliament must first pass an Act to the effect that the resolution must be submitted to a referendum.

\subsection{Judicial Review}

3.4.1 No further points have arisen.

\subsection{The Social Welfare Dimension of the Constitution}

Not relevant.

\subsection{Constitutional Rights and Values in Selected Areas of Global Governance}

No further points have arisen.

\section{References}

Andersen P. (1954) Dansk Statsforfatningsret (Danish constitutional law). Gyldendal, Oslo.

Baumbach T. (2011) The Notion of Criminal Penalty and the Lex Mitior Principle in the Scoppola v. Italy Case. Nordic Journal of International Law 80:125 et seq.

Baumbach T. (2013) Danish criminal law and the EU. EuCLR 3:300 et seq.

Berlin K. (1939) Den Danske forfatningsret (Danish constitutional law). Nyt Nordisk Forlag Arnold Busck, Copenhagen.

Dahl B. (2014) Keynote address. In: Neergaard U., Jacquesson C. (eds.) (2014) Proceedings: Speeches from the XXVI FIDE Congress, Copenhagen, 28-31 May 2014, http://www. fide2014.eu, pp. 26-30.

Dansk Center for Menneskerettigheder og Advokatsamfundet (The Danish Institute for Human Rights and The Danish Bar and Law Society) (2012) Legal guide. http://www. advokatsamfundet.dk/Service/Nyheder/2012/retssikkerhedsguide.aspx.

Elholm T. (2011) Vi, Den Polske Stat, forlanger skinketyven udleveret (We, the Polish state, demand the ham thief be extradited). Advokaten 90(4):28 et seq.

Henrichsen C. (1997) Retssikkerhed og moderne forvaltning (Legal certainty and modern administration). DJØF Publishing, Copenhagen.

Jacqueson C. (2010) Unionsborgerens ret til sociale ydelser efter EU-retten - Hvilken vej blæser vinden? (EU citizens' right to social benefits according to EU law - Which way is the wind blowing?). EU-Ret \& Menneskeret 3:152-166.

Jensen M.H. (1994) Proportionalitetsprincippet (The principle of proportionality). Ugeskrift for Retsvæsen B:235-244. 
Jensen M.H., Jensen J.A. (1991) Afgrænsning af begrebet 'beføjelser, der tilkommer rigets myndigheder' $\mathrm{i}$ grundlovens $\S 20$ (Demarcation of the concept 'powers vested in the authorities' in Article 20 of the Constitution). Ugeskrift for Retsvaesen:281-288.

Koch H. (2008) A Legal Mission: The Emergence of a European 'Rationalized' Natural Law. In: Petersen H. (ed.) Paradoxes of European Legal Integration. Ashgate Publishing, Farnham, pp. $45-63$.

Kristiansen J. (2013) Aftalemodellen og dens europæiske udfordringer (The bargaining model and its European challenges). DJØF Publishing, Copenhagen.

Krunke H. (2003) Den Udenrigspolitiske Kompetence (Foreign policy competence). DJØF Publishing, Copenhagen.

Krunke H. (2005) From Maastricht to Edinburg: The Danish Solution. EuConst 1(3):339-356.

Krunke H. (2007) Developments of National Parliaments' Involvement in Ordinary Foreign Policy and European Policy - Denmark. EPL 13(2):335-348.

Krunke H. (2008-2009) Memorandum on Denmark, in the House of Lords, European Union Committee, $17^{\text {th }}$ Report of Session 2008-09, on Codecision and national parliamentary scrutiny.

Krunke H. (2010) Pensionsreform. De retlige grænser og muligheder. Berettigede forventninger. Generationsfordeling. Demokrati (Pension Reform. The legal limits and possibilities. Legitimate expectations. Generation distribution. Democracy). DJØF Publishing, Copenhagen.

Krunke H. (2013) Engineering Constitutional Change: A Comparative Perspective on Europe, Canada and the USA. Routledge, Abingdon, pp. 73-92.

Krunke H. (2014a) Constitutional identity - seen through a Danish lens. Retfaerd 37(4):24-40.

Krunke H. (2014b) The Danish Lisbon Judgment - Danish Supreme Court, Case 199/2012, Judgment of 20 February 2013. EuConst 10(3):542-570.

Larsen E. (1940) Tvungen Ejendomsafståelse (Forced disposal of property). Nyt Nordisk Forlag Arnold Busck, Copenhagen.

Lauta K.C., Rytter J.E. (2012) Denmark. In: Laffranque J. (ed.) The Protection of Fundamental Rights Post-Lisbon, Reports of the XXV FIDE Congress Tallinn 2012, Vol. 1. Tartu University Press, Tallinn, pp. 389-416.

Mchangama J. (2014) Revision af logningsreglerne (Revision of the regulations on logging). Justitia, 4 September 2014.

Mørup S. (2005) Berettigede forventninger I forvaltningsretten (Legitimate expectations in administrative law). DJØF Publishing, Copenhagen.

Neergaard U., Nielsen R. (2010) Blurring Boundaries: From the Danish Welfare State to the European Social Model. Available on SSRN http://papers.ssrn.com/sol3/papers.cfm?abstract_ id $=1618758$.

Pagh P. (2008) Juridisk Specialudvalg og præjudicielle forelæggelser for EF-domstolen (Legal Special Committee and the preliminary ruling of the ECJ). In: Olsen B.E., Sørensen K.E. (eds.) Europæiseringen af dansk ret (The Europeanisation of Danish law). DJØF Publishing, Copenhagen.

Piris J.C. (2010) The Lisbon Treaty: A legal and Political Analysis. Cambridge Studies in European Law and Policy. Cambridge University Press, Cambridge.

Rasmussen H. (2008) Denmark's Waning Constitutionalism and Article 20 of the Constitution on Transfer of Sovereignty. In Albi A., Ziller J. (eds.) The European Constitution and the National Constitutions: Ratification and Beyond. Kluwer, Alphen aan den Rijn.

Ross A. (1966) Dansk statsforfatningsret II (Danish national law No. 2). Nyt Nordisk Forlag Arnold Busck, Copenhagen.

Rytter J.E. (2010) Dansk-europæisk menneskerettighedsbeskyttelse (Danish-European human rights protection). Juristen 6/7:195 et seq.

Rytter J.E. (2012) Individets grundlæggende rettigheder (The fundamental rights of the individual). Karnov Group, Copenhagen.

Rytter J.E. (2013) Individets grundlæggende rettigheder (The fundamental rights of the individual). Karnov Group, Copenhagen. 
Rytter J.E., Wind M. (2011) In need of juristocracy? The silence of Denmark in the development of European legal norms. ICON 9 (2):470 et seq.

Schulyok F. (2014) In: Giegerich T., Gstrein O.J., Zeitzmann S. (eds.) The EU between 'an Ever Closer Union' and Inalienable Policy Domains of Member States. Nomos Verlagsgesellschaft mbH \& Co. KG, Baden-Baden, pp. 107-152.

Vestergaard J., Adamo S. (2009) National Report: Denmark. In: Vernimment-Van Tiggelen G., Surano L., Weyembergh A. (eds.) The Future of Mutual Recognition in Criminal Matters in the European Union. Editions de l'Université de Bruxelles, Brussels, pp. 147 et seq.

Vestergaard J., Tranberg C.B. (2012) Denmark. In: Laffranque J. (ed.) The Area of Freedom Security and Justice, Including Information Society Issues, Reports of the XXV FIDE Congress Tallinn 2012, Vol. 3. Tartu University Press, Tallinn, pp. 289-317.

Zahle H. (1990) Anmeldelse. Loven i tale, skrift og elektronik (Review. The law in speech, writing and electronics). Juristen 8:398 et seq.

Zahle H. (2001) Dansk Forfatningsret, bind 1 (Danish constitutional law, volume 1). Christian Ejlers Forlag, Copenhagen.

Zahle H. (2006) Dansk Forfatningsret (Danish constitutional law). Christian Ejlers Forlag, Copenhagen.

Zahle H. (2007) Dansk Forfatningsret (studieudgaven) (Danish constitutional law). Christian Ejlers forlag/DJØF Publishing, Copenhagen.

Open Access This chapter is licensed under the terms of the Creative Commons Attribution 4.0 International License (http://creativecommons.org/licenses/by/4.0/), which permits use, sharing, adaptation, distribution and reproduction in any medium or format, as long as you give appropriate credit to the original author(s) and the source, provide a link to the Creative Commons license and indicate if changes were made.

The images or other third party material in this chapter are included in the chapter's Creative Commons license, unless indicated otherwise in a credit line to the material. If material is not included in the chapter's Creative Commons license and your intended use is not permitted by statutory regulation or exceeds the permitted use, you will need to obtain permission directly from the copyright holder. 